NATIONAL BUREAU OF STANDARDS REPORT

10192

\title{
PULL-OUT STRENGTHS OF CLOSELY SPACED DRILLED-IN-INSERTS IN CONCRETE
}

\author{
for \\ Plant Technology Division \\ Post Office Department
}

\section{NBS}

U.S. DEPARTMENT OF COMMERCE

NATIONAL BUREAU OF STANDARDS 


\section{NATIONAL BUREAU OF STANDARDS}

The National Bureau of Standards ' was established by an act of Congress March 3, 1901. Today, in addition to serving as the Nation's central measurement laboratory, the Bureau is a principal focal point in the Federal Government for assuring maximum application of the physical and engineering sciences to the advancement of technology in industry and commerce. To this end the Bureau conducts research and provides central national services in four broad program areas. These are: (1) basic measurements and standards, (2) materials measurements and standards, (3) technological measurements and standards, and (4) transfer of technology.

The Bureau comprises the Institute for Basic Standards, the Institute for Materials Rescarch, the Institute for Applied Technology, the Center for Radiation Research, the Center for Computer Sciences and Technology, and the Office for Information Programs.

THE INSTITUTE FOR BASIC STANDARDS provides the central basis within the United States of a complete and onsistent system of physical measurement; coordinates that system with measurement systems of other nations; and furnishes essential services leading to accurate and uniform physical measurements throughout the Nation's scientific community, industry, and commerce. The Institute consists of an Office of Measurement Services and the following technical divisions:

Applied Mathematics-Electricity-Metrology-Mechanics-Heat-Atomic and Molecular Physics-Radio Physics "-Radio Engineering "-Time and Frequency "-Astrophysics "-Cryogenics."

THE INSTITUTE FOR MATERIALS RESEARCH conducts materials research leading to improved methods of measurement standards, and data on the properties of well-characterized materials needed by industry, commerce, educational institutions, and Government; develops, produces, and distributes standard reference materials; relates the physical and chenical properties of materials to their behavior and their interaction with their environments; and provides advisory and research services to other Government agencies. The Institute consists of an Office of Standard Reference Materials and the following divisions:

Analytical Chemistry-Polymers-Metallurgy_-Inorganic Materials_-Physical Chemistry. THE INSTITUTE FOR APPLIED TECHNOLOGY provides technical services to promote the use of available technology and to facilitate technological innovation in industry and Government; cooperates with public and private organizations in the development of technological standards, and test methodologies; and provides advisory and research services for Federal, state, and local government agencies. The Institute consists of the following technical divisions and offices:

Engineering Standards-Weights and Measurcs - Invention and Innovation - Vehicle Systems Research--Product Evaluation-Building Research-Instrument Shops-Measurement Engineering-Electronic Technology-Technical Analysis.

THE CENTER FÓR RADIATION RESEARCH engages in research, measurement, and application of radiation to the solution of Bureau mission problems and the problems of other agencies and institutions. The Center consists of the following divisions:

Reactor Radiation-Linac Radiation-Nuclear Radiation-Applied Radiation.

THE CENTER FOR COMPUTER SCIENCES AND TECHNOLOGY conducts research and provides technical services designed to aid Government agencies in the selection, acquisition, and effective use of automatic data processing equipment; and serves as the principal focus for the development of Federal standards for automatic data processing equipment, techniqucs, and computer languages. The Center consists of the following offices and divisions:

Information Processing Standards-Computer Information - Computer Services - Systems Development-Information Processing Technology.

THE OFFICE FOR INFORMATION PROGRAMS promotes optimum dissemination and accessibility of scientific information generated within NBS and other agencies of the Federal government: promotes the development of the National Standard Refcrence Data System and a system of information analysis centers dealing with the broader aspects of the National Measurement System, and provides appropriate services to ensure that the NBS staff has optimum accessibility to the scientific information of the world. The Office consists of the following organizational units:

Office of Standard Reference Data-Clearinghouse for Fedcral Scientific and Technical Information "-Office of Technical Information and Publications-Library-Office of Public Information-Office of International Relations.

Headquarters and Laboratories at Gaithersburq. Maryland, unless otherwise noted : mailing address Washington. D.C. 20234. 


\section{NATIONAL BUREAU OF STANDARDS REPORT}

\section{NBS PROJECT}

4213417
April 1970
NBS REPORT

10192

\section{PULL-OUT STRENGTHS OF CLOSELY SPACED DRILLED-IN-INSERTS IN CONCRETE}

by

E. V. Leyendecker and T. W. Reichard

of

Structures Section

Building Research Division

for

Plant Technology Division

Post Office Department

IMPORTANT NOTICE

NATIONAL BUREAU OF ST for use within the Government. and review. For this reason, th whole or in part, is not authol Bureau of Standards, Washingt the Report has been specitically
Approved for public release by the director of the National Institute of Standards and Technology (NIST) on October 9, 2015 ss accounting documents intended subjected to additional evaluation listing of this Report, either in e Office of the Director, National by the Government agency for which zopies for its own use.

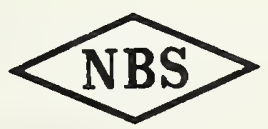

U.S. DEPARTMENT OF COMMERCE

NATIONAL BUREAU OF STANDARDS 


$$
-
$$




\section{NBS REPORT NO. 10192 \\ PULL-OUT STRENGTH OF CLOSELY SPACED, DRILLED-IN-INSERTS IN CONCRETE}

By E. V. Leyendecker and T. W. Reichard

\section{Introduction}

\subsection{General}

There are literally hundreds of types of devices advertised and sold for anchoring, attaching or suspending a fixture, a piece of equipment or some other type of load to an existing structure. These devices can be simple and inexpensive (nail or adhesive) or complicated and expensive (multiple expansion unit). The choice is narrowed, however, when the type of material in which the device is to be used is considered.

Federal Specification FF-S-325 lists about 35 different types of devices suitable for anchoring to solid masonry. Each type is available in a number of sizes. This specification also lists, for most types, a tensile proof test load for each size. The source and reliability of these proof test loads is not known.

The Post Office Department is using many of these devices in their program for the modernization of the mail handling facilities in existing structures. This program calls for the suspension of rather heavy equipment from concrete ceilings. In this application, the reliability of the anchoring device (insert) is of vital importance since even a single failure could be extremely hazardous. 
For heavier equipment the practice is to spread the load to two or more of the anchoring inserts. Here the problem of spacing arises. The distance at which two inserts should be placed so that the pair will carry twice the load of one is not known.

\subsection{Objective}

The objective of this study, as stated in Work Order No. 1 to Project No. 70008, was to determine the minimum spacing for two, three, and four drilledin-insert patterns at which the proof tensile pull-out load indicated in Federal Spec FF-S-325 and Interim Amendment No. 3 is applicable. Three commonly used types of inserts were to be used in determining this spacing.

Secondary objectives were to determine:

(a) The ultimate loads of single and multiple spaced inserts in typical reinforced concrete slabs. (Normal weight and lightweight concrete)

(b) The effect of vibratory loading.

(c) The effect of combining cast-in-place inserts with the drilled-in inserts.

(d) The effect of the depth of the drilled hole.

(e) The effect of over-sized holes.

\section{Test Specimens}

\subsection{Inserts}

Three types of drilled-in-inserts were used in this investigation. Table 1 lists some manufacturer's catalog data while Table 2 gives the Federal Spec FF-S-325 Classification and proof test load for the three inserts. Figure 2.1 is a photograph of these inserts.

Insert Type A is made so that one or more of the expansion units can be used in one hole with one bolt. The Type A data in Tables 1 and 2 are for 
the triple unit as shown in Figure 2.1. Each expansion unit consists of three elements: (a) iron, conical wedge, male part; (b) expanding hard metal ring; (c) lead alloy female part. The conical wedge of the bottommost unit of insert Type $A$ was threaded internally to take the $3 / 4-$ in bolt.

The Type B and C inserts are very similar except that the shell of the Type $B$ (self drilling type) is made to be used as the drill bit for drilling its own hole. Both inserts are made of hardened steel and the shells are internally threaded to take the 3/4-in bolts. The solid steel cone appeared to be identical for both types.

In a few tests a cast-in-place insert was used in combination with the drilled-in-inserts. This cast-in-place insert was the Type 3 insert described in NBS Report 10055 entitled "Design Loads for Inserts Embedded in Reinforced Concrete Slabs"[1] ${ }^{1}$.

\subsection{Concrete Test S1abs}

Thirty four two-way reinforced slabs were cast from five batches of concrete for this study. Twenty seven of these slabs were made from normal weight concrete and the other seven slabs were cast from a semi-lightweight concrete. The properties of the five concretes used in the slabs is presented in Table 3.

Thirty two of the slabs were 5-in thick and reinforced with No. 5 deformed steel bars at 8 -in on centers as indicated in Figure 2.2. The bottom steel

1. Numbers in brackets indicate references listed at the end of this report. 
was placed with $3 / 4-$ in cover. Note that the No. 5 bars were doubled at three locations.

Two of the slabs (A-5 Concrete) were 10-in thick, but were reinforced the same as the others except that 2-No. 4 bars were placed each direction with 3/4-in cover from the top surface for handling purposes.

\subsection{Installation of Inserts}

Holes for the inserts were drilled using an electric rotary hammer. Tungstencarbide tipped, drill bits were used for the Type A and C inserts. A special chucking attachment (provided by the insert manufacturer) was used with the electric hammer in drilling the hole with the Type $B$ insert. The upper 3/4-in of the Type B insert was used for chucking in the special attachment.

The time for drilling the $13 / 8$-in hole for the Type A insert and the 1-in hole for the Type $\mathrm{C}$ was about 1 minute. The time for drilling the hole for the self-drilling Type $B$ insert was about 2 minutes.

The depth of the drilled holes was generally within 1/8-in of the depth specified in Table 1.

The diameter of the drilled holes were about $1 / 32$ in larger than the nominal drill size. The diameter of the hole drilled for the Type $B$ insert with the insert she11 was about $13 / 64$ in.

\subsubsection{Type A Insert}

The Type A insert was installed in the hole in three steps, one step for each of the three expansion units. Each of the units is tightened 
in the hole by "calking".

"Calking" is the process by which the lead female element is driven down over the iron conical wedge, forcing the lead against the sides of the hole. Calking is accomplished by striking the end of a hollow steel cylinder which rests on the lead element. A headless steel bolt, threaded into the bottom threaded wedge, serves as a center guide for the units during the calking.

The driving force exerted during the calking is a variable, but there does appear to be an end-point at which the calking "feels" completed.

\subsubsection{Type $B$ and $C$ Inserts}

The Type $\mathrm{B}$ and $\mathrm{C}$ inserts were installed in the hole by driving the steel shell over the cone at the bottom of the hole. The cone expands the steel shell against the sides of the hole.

As for the Type A insert the driving force is a variable, but the installer could "feel" an end-point.

After installation the 3/4-in chucking-end of the Type $B$ insert (Figure 2.1) was broken off and discarded.

\subsection{Insert Spacing}

Figures 2.3 and 2.4 indicate 12 insert layouts used in the test slabs. The reinforcement had been precisely placed and the layouts designed so that no hole would have to be drilled closer than about 2-in from the center line of the steel bars. 
Inserts were spaced in layouts A, B, C, C, E and G so that more than one test could be performed on one test slab. For instance, Layout A was spaced so that four tests on individual inserts could be performed on a single slab. An additional restraint on the insert location was the necessity of providing a minimum distance of 21 -in from the edge of the test slab to the nearest insert. This distance was necessary to provide a consistent flexural action in the slab during the pull out test (see below for details of test procedure).

\section{Test Apparatus and Procedures}

\subsection{Static Tests}

The static tests were performed using 30 ton hydraulic rams actuated by a single hand operated pump. Groups of inserts were pulled simultaneously by using individual rams connected in parallel.

With this loading system the maximum load attained by the group is controlled by the weakest insert in the group.

The rams were mounted on adjustable span, test stands placed on the test slabs. Figures $3.1,3.2,3.3$, and 3.4 illustrate typical tests on 1,2 , 3 , and 4 inserts. The span of the test stand was adjusted so that the clear distance between the stand supports was 40-in plus the distance between the inserts. This distance was the same as was used in the study on castin-place inserts [1] where it was shown that the flexural action in slabs is an important variable in the load carrying capacity of embedded inserts. The load was applied continuously to the inserts at a rate of 2 -kips per minute per insert until near fallure. Near failure the pumping rate was maintained at the same level as during the early loading. 
During early tests it was observed that the Type B and C inserts were partially drawn from the holes prior to failure. For that reason the vertical movement of the inserts was measured during some of the tests. Figure 3.1 illustrates the method of measuring the vertical movement of the insert relative to the face of the slab, with an LVDT transducer. The load was determined by using a load cell mounted between the ram and pul1-rod. When making vertical movement measurements during a test the complete loadmovement curve was recorded on an $x-y$ plotter. For multiple insert tests the displacement was measured on only one of the inserts in the group.

\subsection{Fatigue Tests}

Fatigue data was developed for a few specimens. Alternating tensile pull-out loads were applied by 10-kip servo-controlled, hydraulic rams operating at about 6 cycles per sec.

The specimens were held to the laboratory tie-down floor so that the clear distance between the tie-down points was $40 \mathrm{in.}$ as for the static tests. The load was alternated between the maximum load and a 3-kip minimum load. 


\section{Discussion of Results}

\subsection{General}

The data for the inserts tested in this program are shown in Tables 4-12. Tests on individual inserts are covered in Sections 4.2 and 4.3. Tests on multiple inserts are covered in Section 4.4. Insert displacement and experimental scatter are covered in sections 4.5 and 4.6 respectively.

It is not possible at this time to derive theoretical expressions for the pull-out loads of drilled-in inserts installed in reinforced concrete slabs. The variables studied in this test program were used to obtain an insight into the load capacity of such inserts and to make design recommendations based on the limited number of tests conducted.

\subsection{Static Tests on Individual Inserts}

\subsubsection{Pull-out Loads}

Failure patterns for individual inserts varied as shown in Figure 4.1. Individual inserts usually pulled out cones of concrete varying from a few inches to eighteen inches in diameter. In one case (of 43) the insert pulled out of the concrete without damaging the concrete surface. In three cases the threads were stripped from the insert (Type A). In two cases the conical wedge pulled through the lead shield (Type A Insert).

The data in this section were obtained from Tables 4, 5, 7, 9 and 10. The average insert pul1-out loads for all of the concrete types 
and compressive strengths are shown in Figure 4.2. As shown in the figure, Insert Type A had pull-out loads that exceeded or equalled those of Insert Type C regardless of concrete type or strength. There are less data available for Insert Type B, but for Concrete A-1 Type $B$ tested between Types $A$ and $C$.

For the semi-lightweight concrete A-3 Type B had a pull-out load slightly greater than Type $A$ and $C$. For the purposes of this testing program Insert Type $\mathrm{C}$ was selected as being the most typical of the three tested as well as serving as a lower bound for the test data. Insert Type A was included in many tests: for comparison. Testing done on Type B was limited since it was almost identical to Type $C$.

A previous test program on cast-in-place inserts [1] indicated that insert pull-out load increased linearly as the square root of the concrete compressive strength. In order to investigate this variable in this study Figure 4.3 was plotted. Data are shown for Type A and Type $\mathrm{C}$ in normal weight concrete, as well as one data point for Type B. The empirical equation for cast-in-place inserts in normal weight concrete is also included for comparison. The one Type 3 castin-place insert used in this testing program is also shown. Insufficient data are available to estimate a good relationship between the strength of the concrete and the pull-out strength. However, the general trend of the data in Figure 4.3 is for the pull-out strength to increase with increasing concrete compressive strength. 
Insert displacement is discussed in Section 4.5. However, it should be noted here that the Type $B$ and $C$ inserts usually pulled out of the concrete about $1 / 2$ inch before the cone of concrete was pulled out with the insert.

\subsubsection{Effect of Depth of Drilled Hole}

The ten inch concrete slab series A-5 (Table 10) was used to determine the effect of the depth of the drilled holes on single-insert, pu11out loads. The test arrangement was similar to tests on the five inch slab. The inserts were always seated in the bottom of the hole as shown in Figure 4.4. Insert Types $\mathrm{A}$ and $\mathrm{C}$ were tested with the results shown in Figure 4.4. For reference each insert was tested at its normal installation depth.

The data for insert type $\mathrm{C}$ indicate that the pull-out load increases at about 1.3 kips per inch of additional depth of the drilled hole, within the limits of the test data. It was observed that although the maximum load increased with an increase in the depth of embedment the method of ultimate failure did not change. In all four of these tests with the Type $\mathrm{C}$ insert the concrete cone pulled out with the insert was approximately the same size (15" diameter circle). Also, as in previous tests, the insert was pulled from the hole until about $1 / 2$ in of the insert was visible before the concrete fracture occurred. Obviously the maximum load must have been attained some time before the cone-pull-out occurred. Displacement measurements were not being 
made during these tests so that the displacement of the insert at maximum load is not known.

The data for Type A indicates that the pull-out load also increases with the depth of the drilled hole. Note that the maximum load for Type $A$ is reached at a drilled depth of $61 / 4 \mathrm{in.}$ At this depth and deeper the inserts fractured (threads stripped off) rather than pulling out a cone of concrete. Thus there is a maximum depth beyond which the pull-out load will not increase, rather the insert will fracture. At a depth of 5 in the insert fractured before reaching the maximum load obtained at $61 / 4 \mathrm{in}$. The reason for this early fracture is not known.

\subsubsection{Effect of Over-Size Holes}

A limited number of tests were conducted on concrete slahs A-2 (Table 5) to determine the effect of over-size holes on the pull-out load of individual inserts. These results are shown in Figure 4.5 for Insert Types $\mathrm{A}$ and $\mathrm{C}$. Type $\mathrm{C}$, with a 1/16 in over-size hole, had a pul1-out load 87 percent of the pull-out load for a properly installed insert. Type $A$, with a hole $5 / 32$ in over-size, had a pull-out load 71 percent of the pull-out load for a properly installed insert. These limited data indicate a strength loss of 13 percent for each $1 / 16$ in of over-size. However, in some instances, properly installed inserts had this much scatter in test results. 


\subsection{Fatigue Tests on Individual Inserts}

The fatigue data for normal weight concrete $(\mathrm{A}-2)$ are shown in Tables 5 and 6 and in Tables 7 and 8 for semi-lightweight concrete (A-3). Note that the concretes had very similar compressive strengths.

The fatigue loading conditions were rather severe with the loads varying between a minimum of 3.0 kips to a maximum which ranged from 68 to 78 percent of the static pull-out strength.

The data is insufficient to reach a strong conclusion on fatigue behavior, but insert failures were a result of either concrete failure or the connecting hardware. This implies that if the connecting hardware does not fail the fatigue behavior of these drilled-in-inserts in concrete will be controlled by the fatigue behavior of the concrete as was found for cast-in-place inserts [1].

\subsection{Static Tests on Multiple Inserts}

\subsubsection{Drilled-in-Inserts}

Typical failure patterns are shown in Figures $3.2,3.3$ and 3.4 for insert groupings of two, three and four respectively. At the smaller spacings the inserts frequently failed as a group. At larger spacings only one insert in the group usually failed.

The variation of pull-out load with insert spacing and grouping is shown in Figure 4.6. The normal weight concrete data are for slab series A-1 (Table 4) and the semi-lightweight concrete data are for 
slab series A-3 (Table 7). Data are shown for Insert Types A and C, although only limited data are available for Type A. The average pul1-out loads shown are for single reference inserts tested in slabs A-1 and A-3. Data obtained from normal weight are shown as solid symbols while data from semi-lightweight concrete are shown as open symbols.

Figure 4.6 shows that pull-out loads vary according to the insert grouping as well as the insert spacing. The strength increase of Type $\mathrm{C}$ for groupings of two, three and four inserts is at approximately the same rate for normal weight and semi-lightweight concrete. The data available for Type A shows an increase in pull-out load with an increase in spacing, except at a much greater rate than for Type C. For this reason Type $\mathrm{C}$ may be used as a lower bound for the inserts tested. The trend of the data indicates that at some maximum spacing the pull-out load on each insert in a group will equal the strength of the pull-out load on a single insert. This will be discussed further in Section 4.4 .3 .

\subsubsection{Combination of Drilled and Cast Inserts}

Concrete Slab Series A-4 (Table 9) was used to determine the pul1-out load capacity of combinations of cast-in-place and drilled-in inserts. In each group one of the inserts was cast-in-place (Type 3), with the remainder being drilled in. Spacing in the groups was dictated by the location of the slab reinforcement.

Test results are shown in Figure 4.7. The top two curves are for similar groups of all drilled-in from Figure 4.6 and are included for 
comparison. The curves are not exactly comparable due to small differences in concrete strengths between the two series of slabs. The groups of combination types of inserts were only 75 to 85 percent of the pull-out strengths of comparable groups of a11-drilled inserts, although the rates of strength increase with increased spacings are similar. The reasons for the pul1-out strength differences are not known.

\subsubsection{Effect of Spacing}

It was shown in Sections 4.4 .1 and 4.4 .2 that the pull-out load per insert in a group increased 1inearly with increased insert spacing. The available data indicate that the rate of increase for a particular type of insert is the same for different groupings and concretes.

The data for Insert Type $\mathrm{C}$ shown in Figures 4.6 and 4.7 is shown in Figure 4.8 with the pull-out loads nondimensionalized. The loads were nondimensionalized by dividing the group pull-out load per insert by the single insert pull-out load for each slab series plotted. This was done to eliminate the effect of concrete strength.

Three important conclusions may be reached from Figure 4.8. These are as follows.

a. The test data definitely forms a family of curves with one curve for each group size.

b. The nondimensionalized data for normal weight and semilightweight concrete are very similar, but the semi-lightweight concrete data are slightly higher than the normal weight. 
c. Data for combinations of drilled and cast-in-place inserts test at about 75 to 85 percent of the results for all-drilled inserts.

These observations may be used to determine an empirical relationship of pul1-out loads with spacing and grouping. Figure 4.9 was plotted to show the relationship.

Figure 4.9 was drawn with the following assumptions:

a. The rate of increase of pull-out strengths with spacing is the same for al1 concrete strengths and types. b. The relative values of pull-out strengths at a particular spacing is the same for all concrete strengths and types.

The vertical axis in Figure 4.9 is the total pull-out load for the group relative to the pul1-out load for a single insert. Thus a single insert has a relative value of unity. Groupings of two, three and four inserts have relative pull-out loads of two, three and four respectively at a sufficiently large spacing.

The range of test data lies between 6 and 18 inches. The curves for spacings greater than 18 inches were obtained by extrapolating the data at the same slope up to the maximum relative pul1-out value for the group. The curves for spacings less than 6 inches were obtained by connecting the data point at 6 inches to a relative value of one at zero inches.

If it were physically possible to space inserts close enough so that they occupied the same space, then two inserts would carry no 
more than one insert. The same is true for three or four inserts. In actual practice the inserts cannot be spaced any closer than one insert diameter. For the tested inserts it is recommended that they be spaced no closer than three inches. This is due to two reasons. First the data for spacings were obtained by extrapolation. In the 3 in region the insert failure modes may change from the one assumed. Secondly the wall of concrete separating holes may crack if inserts are spaced too close together. This could further affect the pull-out strength.

\subsection{Displacement}

The displacement of inserts relative to the slab surfaces during static pul1-out tests are shown in Table 11. Displacements are given for Insert Types A, B and C for several concrete strengths and groupings at 3.0 and $6.0 \mathrm{kip} 10 \mathrm{ad}$ levels. The displacement at the $6.0 \mathrm{kip} 1 \mathrm{oad}$ is two to three times that displacement at the $3.0 \mathrm{kip} 10 a d$ level in normal weight concrete. In semi-lightweight concrete it is three to six times as large.

The complete load vs displacement curve for a typical insert is shown in Figure 4.10. Note that the displacement increases rapidly for loads larger than 4.0 kips. For this reason a maxium service load of about 3.0 kips per insert would be reasonable. 


\subsection{Experimental Scatter}

Average pull-out loads on single inserts installed in several different concrete strengths and types are shown in Table 12. A lower pull-out load limit based on a 99 percent probability that an insert pull-out load will be larger is also shown. The ratios of the lower limit to the average pu11-out load are about 0.75 for all concrete strengths and types. Thus average pull-out loads should be multiplied by 0.75 to account for experimental scatter.

\subsection{Proof Load}

The proof load given in FF-S-325 for the Type A insert is $7.3 \mathrm{kips}$ and for the Type $B$ and $C$ insert it is 7.1 kips. The pull-out load on a single insert and the total pull-out load on insert groups exceeded this proof load in all cases for the static tests covered in this report. In fact the pul1-out load per insert in group loadings exceeded the proof load except for the group of four inserts at the six inch spacing in the semilightweight concrete.

\section{Conclusions and Recommendations}

\subsection{Individual Inserts}

\section{1 .1 Pul1-Out Loads}

It was shown in this study that insert pull-out loads vary with insert type and concrete strength and type. The exact variation of insert pull-out load with concrete strength was not determined; 
however, estimated average pull-out loads can be made for selected concrete strengths as shown below in normal weight concrete (refer to Figure 4.3 ).

$\begin{array}{ccc}f_{c}^{\prime}, \text { psi } & \begin{array}{c}\text { Type A } \\ \text { Pul1-Out Load } \\ \text { kips }\end{array} & \begin{array}{c}\text { Type B and C } \\ \text { Avg. Pu11-Out Load } \\ \text { kips }\end{array} \\ 3000 & 12.2 & 9.6 \\ 3500 & 13.5 & 11.5 \\ 4000 & 13.5 & 12.8\end{array}$

Note that Type B insert is assumed equivalent to Type C insert although it may be somewhat better. These pul1-out loads exceed the Federal proof load of 7.1 kips for Types $B$ and $C$ inserts and 7.3 kips for Type A. The above loads should be multiplied by 0.70 to obtain the pull-out capacity in semi-1ightweight concrete of equal compressive strengths.

\subsubsection{Depth-of-Hole}

The data for Insert Type C indicate a strength increase of 1.3 kips per inch of additional depth for $\mathrm{f}_{c}^{\prime}=2830$ psi. Tests on Type A indicate that there is a depth at which the insert itself will fracture and no further load increase is possible. It is recommended that this be neglected in design, but if the additional load carrying capacity is needed it should not exceed the limits of test data shown in Figure 4.4 (maximum depth of $71 / 2$ in).

\section{1 .3 Over-Size Holes}


The limited data available (four tests) indicates strength losses of 13 percent for an increase of 1/16 inch in the hole size. This may be neglected in design since it is felt to be covered by an experimental scatter factor discussed later.

\section{1 .4 Fatigue}

Fatigue test results were erratic for the severe loading condition discussed in this report. It is recommended that a reduction factor of 0.65 be used for fatigue loading.

\subsubsection{Reduction Factors}

The pul1-out loads in Section 5.1 .1 are average pull-out loads and should be reduced to account for concrete type and experimental scatter. It is recommended that these loads be multiplied by 0.75 to obtain a lower bound for experimental scatter. In the case of semi-lightweight concrete the loads should also be multiplied by 0.70 . An additional reduction of 0.65 should be included for fatigue. The reduced pull-out loads may be converted to design loads by the use of a suitable load factor. One such load factor in common use in reinforced concrete is 1.8 [2]. The pull-out loads in Section 5.1.1 reduced by the reduction factors and the load factor are shown below.

\begin{tabular}{ccccc}
$f_{c}^{\prime}$, psi & \multicolumn{2}{c}{$\begin{array}{c}\text { Normal weight Concrete } \\
\text { Reduced Load, kips } \\
\text { Type A }\end{array}$} & \multicolumn{2}{c}{$\begin{array}{c}\text { Semi-Lightweight Concrete } \\
\text { Reduced Load, kips }\end{array}$} \\
\hline 3000 & 3.3 & 2.6 & 2.3 & 1.8 \\
3500 & 3.7 & 3.1 & 2.6 & 2.2 \\
4000 & 3.7 & 3.5 & 2.6 & 2.5
\end{tabular}


As indicated in 4.5 the maximum load should be limited to $3.0 \mathrm{kips}$ to control displacement. Thus the above pull out loads that exceed 3.0 kips should be reduced, resulting in the loads below.

Design Loads

\begin{tabular}{ccccc} 
& \multicolumn{2}{c}{$\begin{array}{c}\text { Normal weight Concrete } \\
\text { Load, kips } \\
\text { Type B and C }\end{array}$} & $\begin{array}{c}\text { Semi-Lightweight Concrete } \\
\text { Load, kips } \\
\text { Type A }\end{array}$ \\
\hline 3000 & 3.0 & 2.6 & 2.3 & 1.8 \\
3500 & 3.0 & 3.0 & 2.6 & 2.2 \\
4000 & 3.0 & 3.0 & 2.6 & 2.5
\end{tabular}

\subsection{Multiple Inserts}

Although the range of data (6 in to 18 in spacing) was limited, Figure 4.9 repeated as Figure 5.1 with one modification appears reasonable. Figure 5.1 shows the group strengths converging to unity at the recommended minimum spacing of three inches rather than the spacing of zero inches. This was done for safety since the failure mode may change for inserts spaced too closely together.

Figure 5.1 may be used for design by determining the average single insert pul1-out load as recommended in Section 5.1, then enter Figure 5.1 at the proper group spacing and read the relative pull-out load from the appropriate group curve. If the group is a combination of one cast-inplace insert with the remainder drilled, the load capacity determined from the curves should be multiplied by 0.75 . 


\section{Acknowledgements}

The work described herein was carried out in the structural laboratories of the Building Research Division at the National Bureau of Standards. The program was sponsored by the U. S. Post Office Department. Liaison was provided by W. J. Werner (now with HUD) and George Bergdolt. 


\section{References}

1. Reichard, T. W., Carpenter, E. F., and Leyendecker, E. V., "Design Loads for Inserts Embedded in Reinforced Concrete Slabs," NBS Report 10055, July 1969.

2. American Concrete Institute. Building Code Requirements for Reinforced Concrete (ACI-318), Detroit, Michigan, June 1963. 
TABLE 1 Manufacturer's Catalog Data for Drilled-In Inserts I/

\begin{tabular}{|c|c|c|c|c|}
\hline $\begin{array}{l}\text { NBS } \\
\text { Type }\end{array}$ & $\begin{array}{l}\text { Brand } \\
\text { Name }\end{array}$ & $\begin{array}{l}\text { Drill } \\
\text { Size }\end{array}$ & $\begin{array}{c}\text { Depth of } \\
\text { Hole }\end{array}$ & $\begin{array}{l}\text { Average } \\
\text { Pull Out Load }\end{array}$ \\
\hline & & in. & in. & kips \\
\hline A & $\begin{array}{l}\text { National Lead, } \\
\text { Cinch Type } 2\end{array}$ & $13 / 8$ & $33 / 4$ & --- \\
\hline B & $\begin{array}{l}\text { Red Head, Self- } \\
\text { drilling } \\
\text { Cat. No. S-34 }\end{array}$ & None & $31 / 4$ & 17.7 \\
\hline C & $\begin{array}{l}\text { Red Head Flush } \\
\text { Cat. No. J-34 }\end{array}$ & 1 & $33 / 16$ & 17.2 \\
\hline
\end{tabular}

Note:1/ All inserts are for use with $3 / 4$ in. bolts. 
TABLE 2 Drilled-In Insert Classification by Fed. Spec. FF-S-325

\begin{tabular}{llc}
$\begin{array}{l}\text { NBS } \\
\text { Type }\end{array}$ & $\begin{array}{c}\text { FF-S-325 } \\
\text { Type }\end{array}$ & $\begin{array}{c}\text { Tensile Proof } \\
\text { Test Load } \\
\text { Ib }\end{array}$ \\
\hline A & Group I, Type I, Class 2 & 7325 I/ \\
B & Group III, Type I & 7100 \\
C & Group VIII, Type I & 7100
\end{tabular}

Note: 1/ Triple unit. 
TABLE 3 Concrete Properties

\begin{tabular}{l|c|c|c|c|c|c}
\hline $\begin{array}{c}\text { Batch } \\
\text { No. }\end{array}$ & \multicolumn{2}{|c|}{ Mix } & Slump & \multicolumn{2}{c|}{ Strength } & \multicolumn{2}{c}{$\begin{array}{c}\text { Age } \\
\text { Cement Content }\end{array}$} & Coarse Aggregate & & Compressive & Splitting & pt Test \\
\hline & sacks/cu. yd. & & in. & psi & psi & days \\
\hline A-1 & 5 & Normal weight & $51 / 2$ & 3700 & 400 & 64 \\
A-2 & 5 & Normal weight & 5 & 4240 & 400 & 70 \\
A-3 & 6 & Lightweight & $31 / 2$ & 4290 & 310 & 63 \\
A-4 & 5 & Normal weight & 6 & 3320 & 380 & 24 \\
A-5 & 5 & Normal weight & $51 / 2$ & 2830 & -- & 10
\end{tabular}

Note: I/ Strengths, at time of pull-out tests. 
TABLE 4 Static Pull-Out Tests on A-1 Concrete Slabs, $\mathrm{f}_{\mathrm{c}}^{\prime}=3700$ psi

\begin{tabular}{|c|c|c|c|c|c|c|c|c|}
\hline \multirow{3}{*}{$\begin{array}{l}\text { Slab } \\
\text { No. }\end{array}$} & \multirow{3}{*}{$\begin{array}{l}\text { Inserts } \\
\text { per Test }\end{array}$} & \multirow{3}{*}{$\begin{array}{l}\text { Spacing } \\
\text { of Inserts }\end{array}$} & \multicolumn{6}{|c|}{ Average Static Pull-out Load } \\
\hline & & & \multicolumn{2}{|c|}{ Insert A } & \multicolumn{2}{|c|}{ Insert $B$} & \multicolumn{2}{|c|}{ Insert $\mathrm{C}$} \\
\hline & & & $\begin{array}{l}\text { No. of } \\
\text { Tests }\end{array}$ & $\begin{array}{l}\text { kips/ } \\
\text { insert }\end{array}$ & $\begin{array}{l}\text { No. of } \\
\text { Tests }\end{array}$ & $\begin{array}{l}\text { kips / } \\
\text { insert }\end{array}$ & $\begin{array}{l}\text { No. of } \\
\text { Tests }\end{array}$ & $\begin{array}{l}\text { kips / } \\
\text { insert }\end{array}$ \\
\hline 1 & 1 & --- & 2 & 15.0 & 1 & 12.6 & 1 & 12.7 \\
\hline 2 & 2 & 6 & 1 & 9.6 & - & ---- & 1 & 9.4 \\
\hline 3 & 2 & 12 & 1 & 14.4 & - & ---- & 1 & 11.9 \\
\hline 4 & 2 & 18 & - & ---- & - & ---- & 2 & 11.8 \\
\hline 5 & 3 & $12 \times 12$ & - & ---- & - & ---- & 1 & 10.5 \\
\hline 6 & 4 & $6 \times 6$ & - & ---- & - & --- & 2 & 8.7 \\
\hline 7 & 1 & --- & 2 & 13.8 & - & --- & 2 & 12.2 \\
\hline 8 & 1 & --- & 1 & 11.6 & 2 & 13.5 & 1 & 11.6 \\
\hline 9 & 4 & $18 \times 18$ & - & --- & - & --- & 1 & 10.5 \\
\hline 10 & 4 & $12 \times 12$ & - & --- & - & --- & 1 & 9.5 \\
\hline 11 & 3 & $6 \times 6$ & - & --- & - & ---- & 2 & 9.0 \\
\hline 12 & 2 & 6 & 1 & 10.3 & - & ---- & 1 & 11.0 \\
\hline 13 & 2 & 12 & 1 & 13.3 & - & --- & 1 & 10.7 \\
\hline 14 & 1 & --- & 1 & 12.0 & 1 & 11.5 & 2 & 11.4 \\
\hline
\end{tabular}

Notes: 1. Loads shown for the multiple pulls are the average for a single insert at the first failure. The total load carried by the group, or pair, in the multiple pulls is the recorded average times the number of inserts.

2. These recorded loads for the grouped inserts are at the failure of the first insert in the group. The remaining inserts would have been able to carry a larger load per insert, thus the recorded load is a lower bound load per insert for the group. 
TABLE 5 Pul1-Out Tests on A-2 Concrete Slabs, $\mathrm{f}_{\mathrm{C}}^{\prime}=4240 \mathrm{psi}$

\begin{tabular}{|c|c|c|c|c|c|c|}
\hline \multirow{3}{*}{$\begin{array}{l}\text { Slab } \\
\text { No. }\end{array}$} & \multirow{3}{*}{$\begin{array}{c}\text { Type of } \\
\text { Test }\end{array}$} & \multicolumn{4}{|c|}{ Number of tests and average load } & \multirow[t]{3}{*}{ Remarks } \\
\hline & & \multicolumn{2}{|c|}{ Insert $\mathrm{A}$} & \multicolumn{2}{|c|}{ Insert $\mathrm{C}$} & \\
\hline & & No. & kips/insert & No. & kips/insert & \\
\hline 1 & $\begin{array}{l}\text { Individual } \\
\text { static }\end{array}$ & 2 & 13.3 & 2 & 13.3 & -- \\
\hline 2 & Fatigue & 2 & -- & 2 & ---- & $\begin{array}{l}\text { Accidently } \\
\text { cracked }\end{array}$ \\
\hline 3 & $\begin{array}{l}\text { Individual } \underline{2} / \\
\text { static }\end{array}$ & 2 & $9.41 /$ & 2 & 11.6 & $\begin{array}{c}\text { Oversized } 2 / \\
\text { holes }\end{array}$ \\
\hline 4 & Fatigue & 2 & --- & 2 & ---- & See Table 6 \\
\hline
\end{tabular}

Notes: $1 /$ Threaded cones pulled through bottom lead shield of Insert A.

$2 /$ Holes for Insert A was drilled $19 / 16^{\prime \prime}$ diameter $=5 / 32^{\prime \prime}$ oversize

Holes for Insert $C$ was drilled $13 / 32^{\prime \prime}$ diameter $=1 / 16^{\prime \prime}$ oversize 
TABLE 6 Fatigue Tests on Individual Inserts in A-2 Concrete Slabs

\begin{tabular}{|c|c|c|c|c|c|}
\hline \multirow{2}{*}{$\begin{array}{l}\text { Insert } \\
\text { Type }\end{array}$} & \multirow{2}{*}{$\begin{array}{l}\text { Slab } \\
\text { No. }\end{array}$} & \multicolumn{2}{|c|}{$\mathrm{P}_{\max } \underline{1 /}$} & \multirow{2}{*}{$\begin{array}{c}\text { Cycles } \\
\text { at Failure }\end{array}$} & \multirow[t]{2}{*}{ Remarks } \\
\hline & & $\overline{\text { kips }}$ & $\% \mathrm{P}$ & & \\
\hline A & 4 & 9.0 & 68 & $(554,000)$ & $\begin{array}{l}\text { Insert did } \\
\text { not fail - } \\
\text { bolt broke }\end{array}$ \\
\hline A & 4 & 10.0 & 75 & $(475,700)$ & $\begin{array}{l}\text { Insert did } \\
\text { not fail - } \\
\text { bolt broke }\end{array}$ \\
\hline $\mathrm{C}$ & 4 & 10.0 & 75 & 3,300 & $\begin{array}{l}\text { Concrete } \\
\text { spalled }\end{array}$ \\
\hline C & 4 & 9.8 & 73 & 141,600 & $\begin{array}{l}\text { Concrete } \\
\text { spalled }\end{array}$ \\
\hline
\end{tabular}

1/ $\mathrm{P}_{\max }$ is the maximum cyclic load

$\mathrm{P}_{\mathrm{u}}$ is the average static pull-out load for the insert in slab No. 1 (13.3 kips).

The minimum load was 3.0 kips for all fatigue tests. 
TABLE 7 Static Pull-Out Tests on A-3 Semi-Lightweight Concrete Slabs, $f_{c}^{\prime}=4290 \mathrm{psi}$

\begin{tabular}{|c|c|c|c|c|c|c|}
\hline \multirow{3}{*}{$\begin{array}{l}\text { Slab } \\
\text { No. }\end{array}$} & \multirow{3}{*}{$\begin{array}{r}\text { Inserts } \\
\text { per test }\end{array}$} & \multicolumn{4}{|c|}{ Number of Tests and Average Static Pu11-Out Load } & \multirow{2}{*}{$\begin{array}{l}\text { Spacing of } \\
\text { Multiple } \\
\text { Pulls }\end{array}$} \\
\hline & & \multicolumn{2}{|c|}{ Insert A } & \multicolumn{2}{|c|}{ Insert $\mathrm{C}$} & \\
\hline & & Tests & kips/insert & Tests & kips/insert & \\
\hline 1 & 1 & 2 & 9.1 & 2 & 9.4 & -- \\
\hline $2^{1 /}$ & 1 & 1 & 8.2 & 1 & 7.7 & -- \\
\hline 3 & 2 & - & --- & 2 & 7.8 & $\begin{array}{l}2 \text { inserts } \\
6^{\prime \prime}\end{array}$ \\
\hline 4 & 2 & - & -- & 2 & 8.4 & $\begin{array}{l}2 \text { inserts } \\
12^{\prime \prime}\end{array}$ \\
\hline 5 & 4 & - & --- & 2 & 6.7 & $\begin{array}{l}4 \text { inserts } \\
6^{\prime \prime} \times 6^{\prime \prime}\end{array}$ \\
\hline 6 & 4 & - & --- & 1 & 7.5 & $\begin{array}{c}4 \text { inserts } \\
12^{\prime \prime} \times 12^{\prime \prime}\end{array}$ \\
\hline 7 & 1 & 1 & $10.12 /$ & - & --- & See Table 8 \\
\hline
\end{tabular}

Notes: 1/ Two tests on this slab with Insert $B$ averaged 9.3 kips.

2/ Static pull-out load following fatigue test. 
TABLE 8 Fatigue Tests on Individual Inserts in Slab 7 of A-3 Concrete

\begin{tabular}{ccccc}
$\begin{array}{c}\text { Insert } \\
\text { Type }\end{array}$ & \multicolumn{2}{c}{$\mathrm{P}_{\max }$} & \multicolumn{1}{c}{$\begin{array}{c}\text { Cycles } \\
\text { at failure }\end{array}$} & Remarks \\
\cline { 2 - 5 } & 6.9 & 78 & $10^{6}$ & Did not fail in fatigue \\
C & 6.6 & 75 & 14,460 & \\
C & 6.0 & 68 & $>550,000$ & Accidently overloaded
\end{tabular}

Note: $\mathrm{P}_{\mathrm{u}}=8.8 \mathrm{kips}$ and $\mathrm{P}_{\min }=3.0 \mathrm{kips}$ for all tests. 


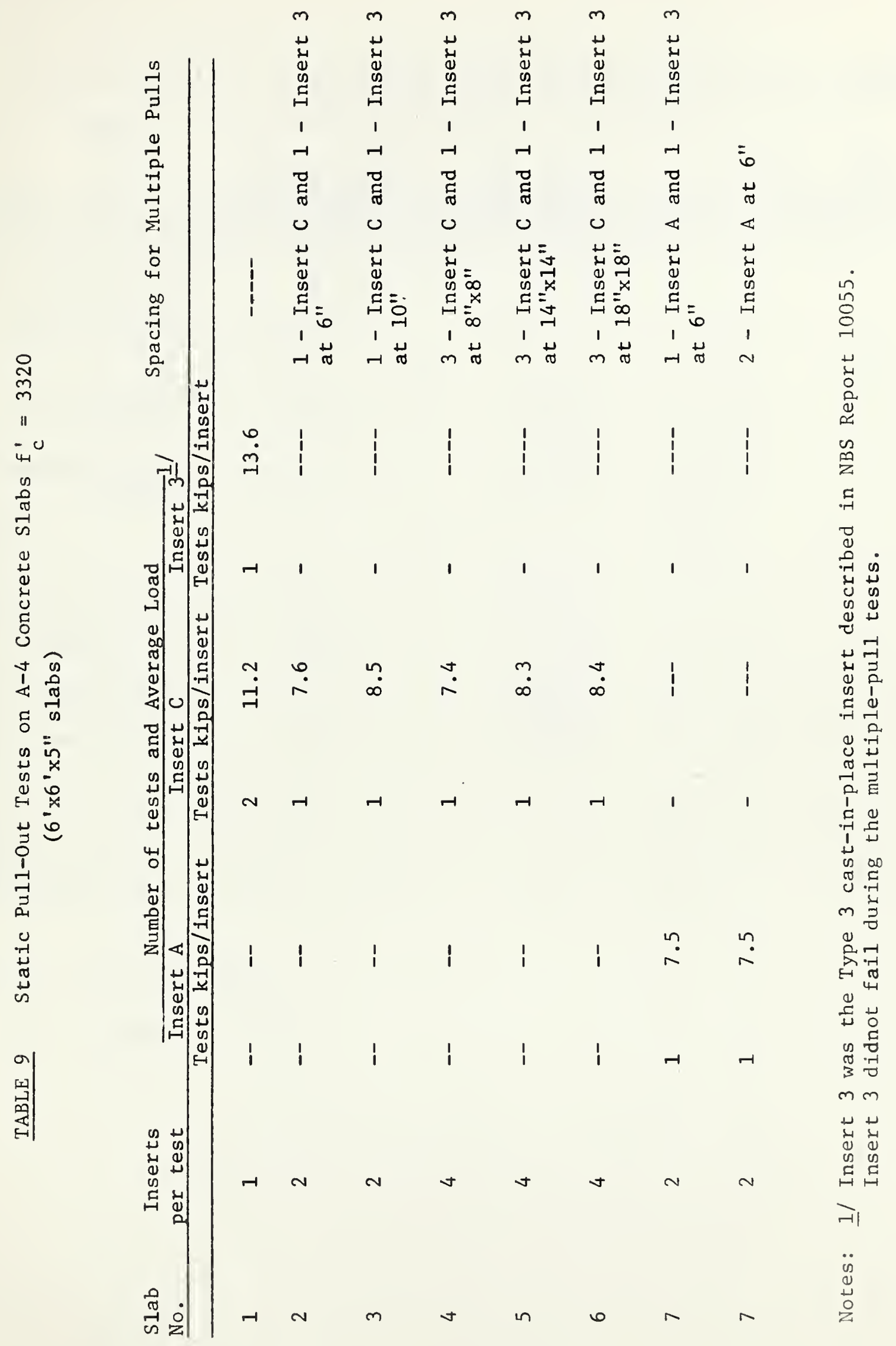


TABLE 10 Static Pul1-Out Tests on Individual Inserts in A-5 Concrete Slabs

\begin{tabular}{|c|c|c|c|c|}
\hline $\begin{array}{l}\text { Slab } \\
\text { No. }\end{array}$ & $\begin{array}{l}\text { Insert } \\
\text { Type }\end{array}$ & $\begin{array}{c}\text { Depth of } \\
\text { Drilled Hole }\end{array}$ & $\begin{array}{l}\text { Pull-Out Load } \\
\text { Maximum }\end{array}$ & Failure \\
\hline & & in. & kips & \\
\hline 1 & A & $33 / 4$ & 11.8 & Concrete Cone \\
\hline 1 & A & 5 & 14.2 & $\begin{array}{l}\text { Stripped threads } \\
\text { on insert }\end{array}$ \\
\hline 1 & A & $61 / 4$ & 24.0 & $\begin{array}{l}\text { Stripped threads } \\
\text { on insert }\end{array}$ \\
\hline 1 & A & $71 / 2$ & 23.6 & $\begin{array}{l}\text { Stripped threads } \\
\text { on insert }\end{array}$ \\
\hline 2 & $\mathrm{C}$ & $33 / 16$ & 8.6 & Concrete cone \\
\hline 2 & $\mathrm{C}$ & 5 & 11.3 & Concrete cone \\
\hline 2 & $\mathrm{C}$ & $61 / 4$ & 12.2 & Concrete cone \\
\hline 2 & C & $71 / 2$ & 15.4 & Concrete cone \\
\hline
\end{tabular}


TABLE 11 Vertical Movement of Inserts During Static Pu11-Out Tests

\begin{tabular}{|c|c|c|c|c|c|c|c|}
\hline \multirow[t]{2}{*}{ Concrete } & \multirow{2}{*}{$\begin{array}{l}\text { Slab } \\
\text { No. }\end{array}$} & \multicolumn{3}{|c|}{ Movement at 3.0 kips Load } & \multicolumn{3}{|c|}{ Movement \& 6.0 kips Load } \\
\hline & & Insert $\mathrm{A}$ & Insert $B$ & Insert C & Insert A & Insert B & Insert C \\
\hline & & in. & in. & in. & in. & in. & in. \\
\hline \multirow[t]{3}{*}{$A-1$} & 6 & --- & --- & 0.02 & --- & --- & 0.06 \\
\hline & 7 & $0.02^{2}=$ & -- & 0.02 & 0.04 & --- & 0.05 \\
\hline & 8 & 0.02 & $0.04 \frac{21}{1}$ & 0.03 & 0.04 & $0.07 \frac{21}{1}$ & 0.09 \\
\hline \multirow[t]{2}{*}{$A-2$} & 1 & $0.01 \underline{1 /}$ & --- & $0.01^{1 /}$ & $0.03^{2 /}$ & --- & $0.05^{21}$ \\
\hline & $3^{1 /}$ & $0.02^{2 /}$ & --- & $0.03^{2 /}$ & $0.05^{2 /}$ & --- & $0.06^{2 /}$ \\
\hline \multirow[t]{6}{*}{$A-3$} & 1 & 0.02 & -- & 0.05 & 0.06 & --- & 0.11 \\
\hline & 2 & 0.02 & 0.02 & 0.03 & 0.05 & 0.11 & 0.34 \\
\hline & 3 & --- & --- & 0.02 & -- & -- & 0.09 \\
\hline & 4 & -- & -- & $0.02^{2 /}$ & --- & --- & $0.14 \frac{21}{1}$ \\
\hline & 5 & -- & -- & $0.01^{2 /}$ & --- & --- & $0.14 \frac{2 /}{}$ \\
\hline & 6 & -- & --- & 0.03 & --- & --- & 0.34 \\
\hline Normal wt? & Avg. & 0.02 & 0.04 & 0.02 & 0.04 & 0.07 & 0.06 \\
\hline Lightweigh & t Avg. & 0.02 & 0.02 & 0.03 & 0.06 & 0.11 & 0.19 \\
\hline
\end{tabular}

Note $1 /$ Oversized holes

2/ Average of 2 tests. 
TABLE 12 Statistical Data for Pull-Out Tests on Single Inserts

\begin{tabular}{|c|c|c|c|c|c|}
\hline Insert & $\begin{array}{l}\text { Concrete } \\
\text { Type \& Com- } \\
\text { pressive } \\
\text { Strength }\end{array}$ & $\mathrm{n}$ & $\overline{\mathrm{X}}$ & S & $\begin{array}{c}\text { Lower } \\
\text { Limit } \\
\text { for } 99 \% \\
\text { Probability } \\
(\bar{X}-2 S) \\
\end{array}$ \\
\hline & $\mathrm{psi}$ & & kips & kips & kips \\
\hline A11 & $\begin{array}{l}\text { Normal wt. } \\
3320-4240\end{array}$ & 22 & 12.7 & 1.7 & 9.3 \\
\hline Al1 & $\begin{array}{l}\text { Lt. wt. } \\
4290 \text { psi }\end{array}$ & 9 & 9.1 & .9 & 7.3 \\
\hline A & $\begin{array}{l}\text { Normal wt. } \\
3700-4240\end{array}$ & 8 & 13.5 & 1.8 & 9.9 \\
\hline A & $\begin{array}{l}\text { Lt. wt. } \\
4290\end{array}$ & 4 & 9.1 & .8 & 7.5 \\
\hline B & $\begin{array}{l}\text { Normal wt. } \\
3700\end{array}$ & 4 & 12,8 & 1.9 & 9.0 \\
\hline B & $\begin{array}{l}\text { Lt. wt. } \\
4290\end{array}$ & 1 & 10.4 & --- & --- \\
\hline $\mathrm{C}$ & $\begin{array}{l}\text { Normal wt. } \\
3700-4240\end{array}$ & 8 & 12.2 & 1.3 & 9.6 \\
\hline C & $\begin{array}{l}\text { Lt. wt. } \\
4290\end{array}$ & 3 & 8.8 & 1.0 & 6.8 \\
\hline
\end{tabular}

Note: $\mathrm{n}=$ Number of tests

$\overrightarrow{\mathrm{X}}=$ Average value

$S=$ Standard deviation 

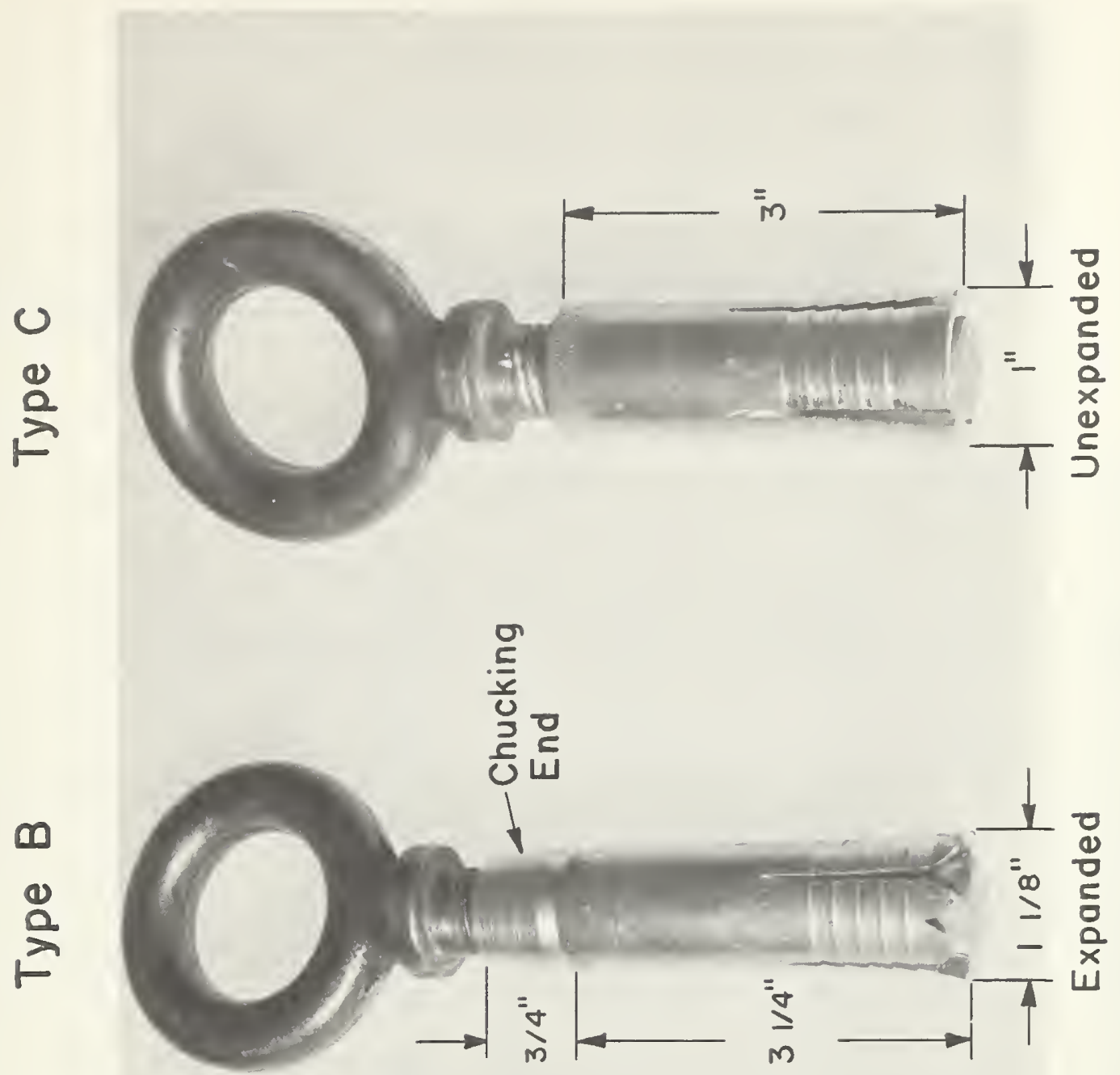



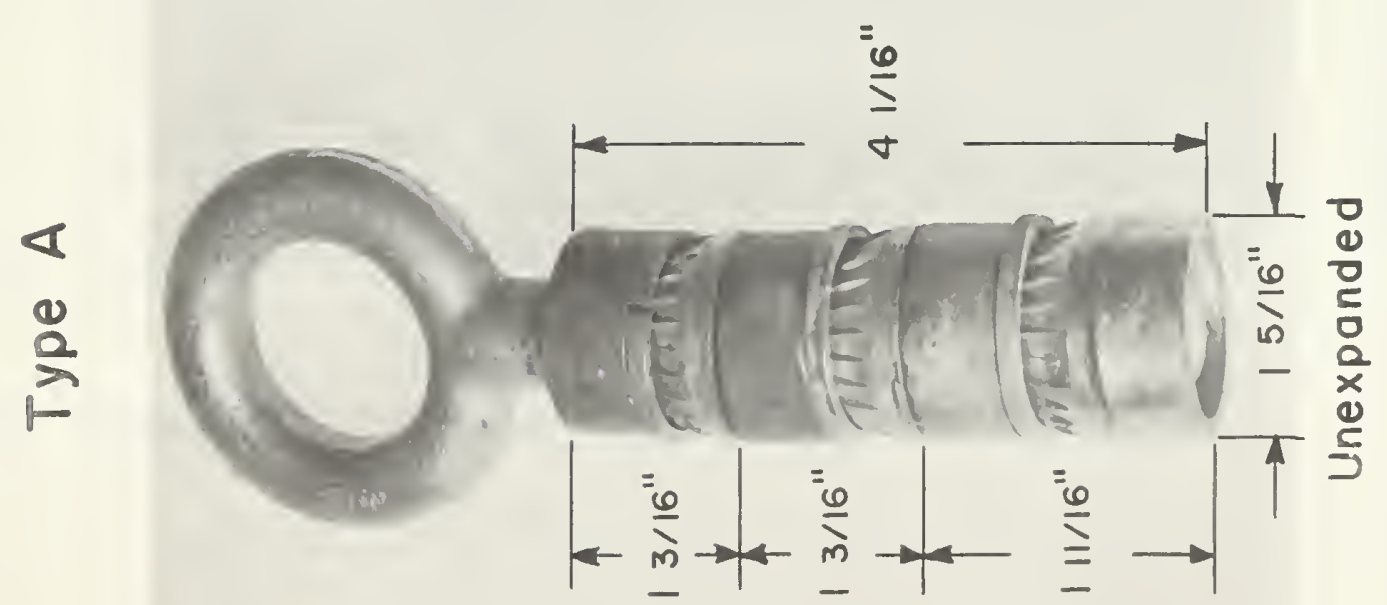




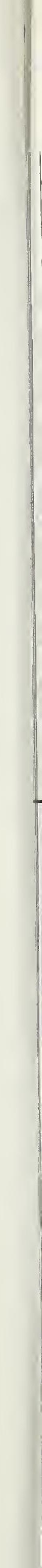




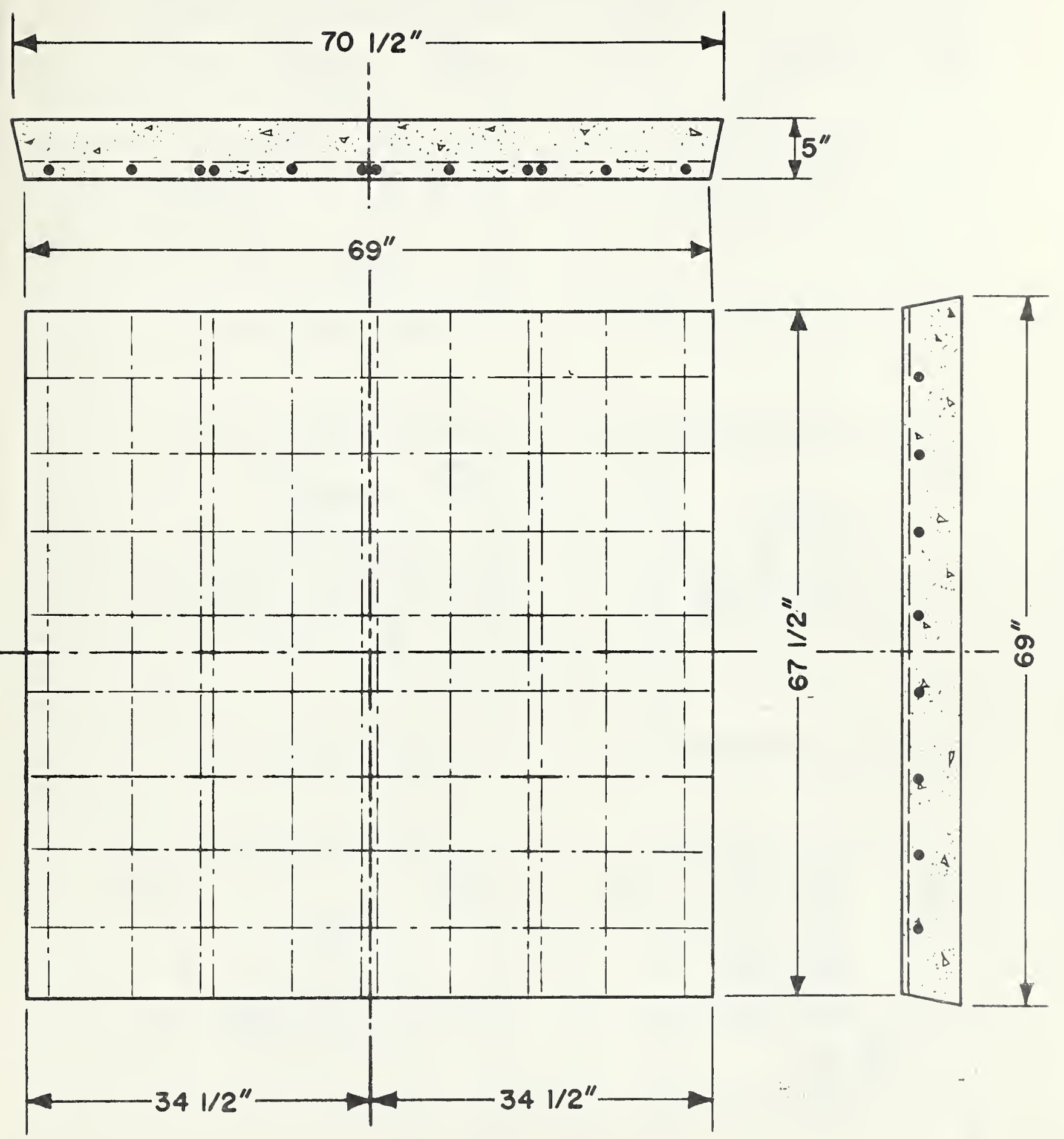

Figure 2.2 Test Slab Dimensions and Reinforcement 

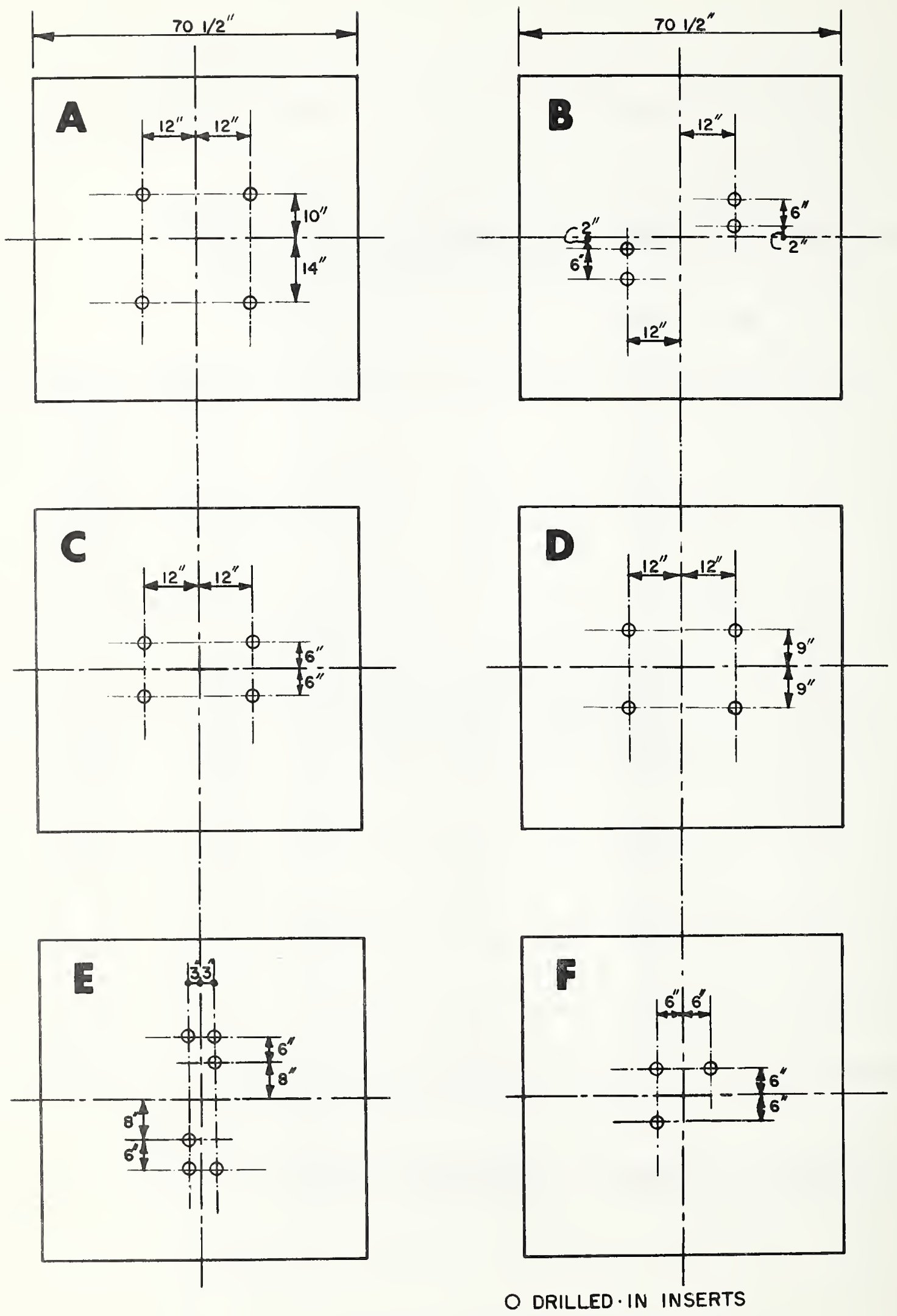

F1gure 2.3 Insert Arrangements A-F 

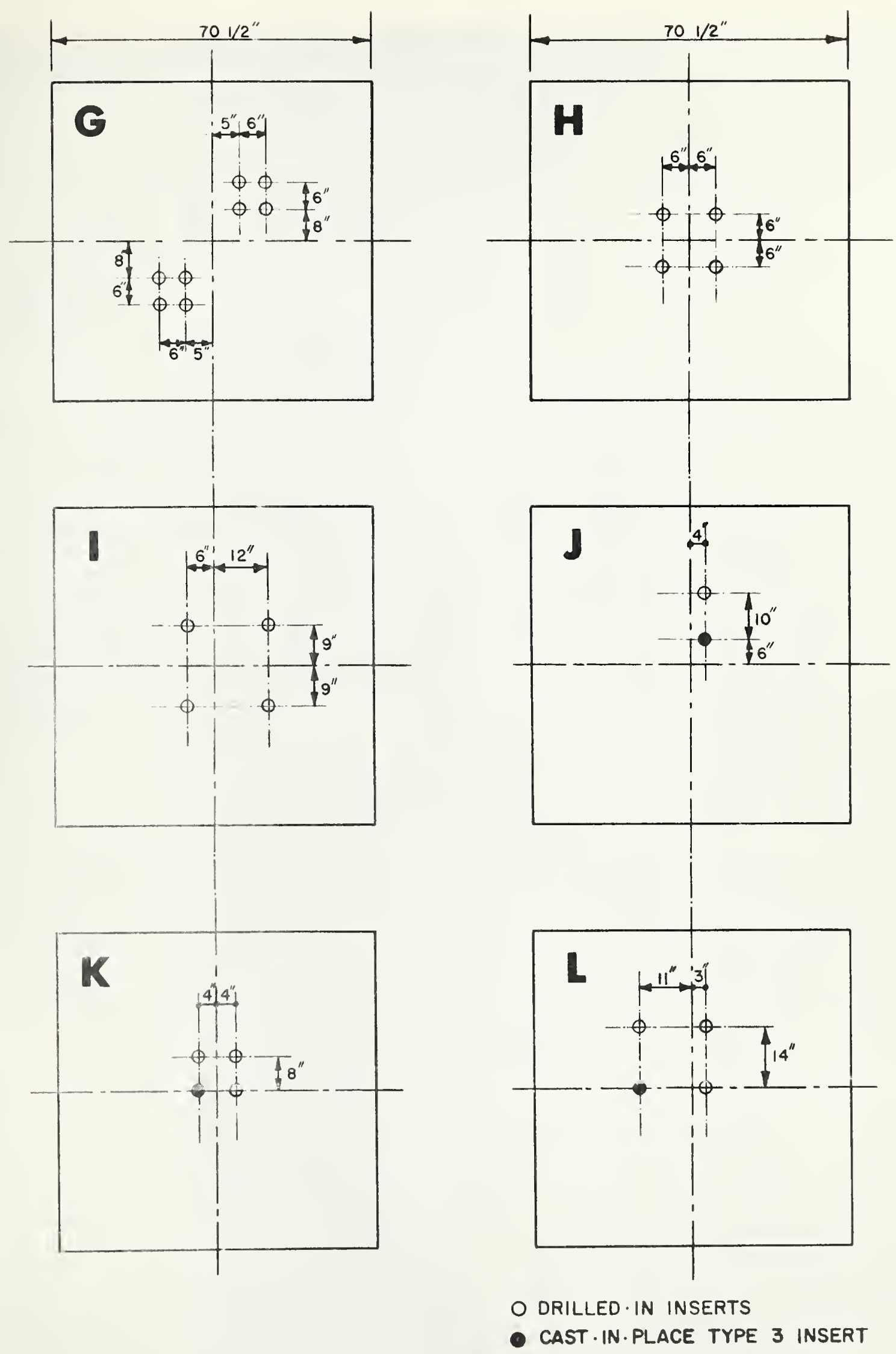

Figure 2.4 Insert Arrangements G-L 


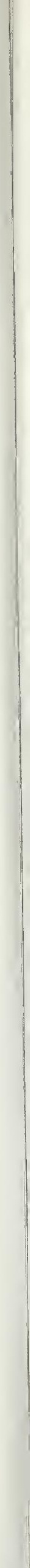




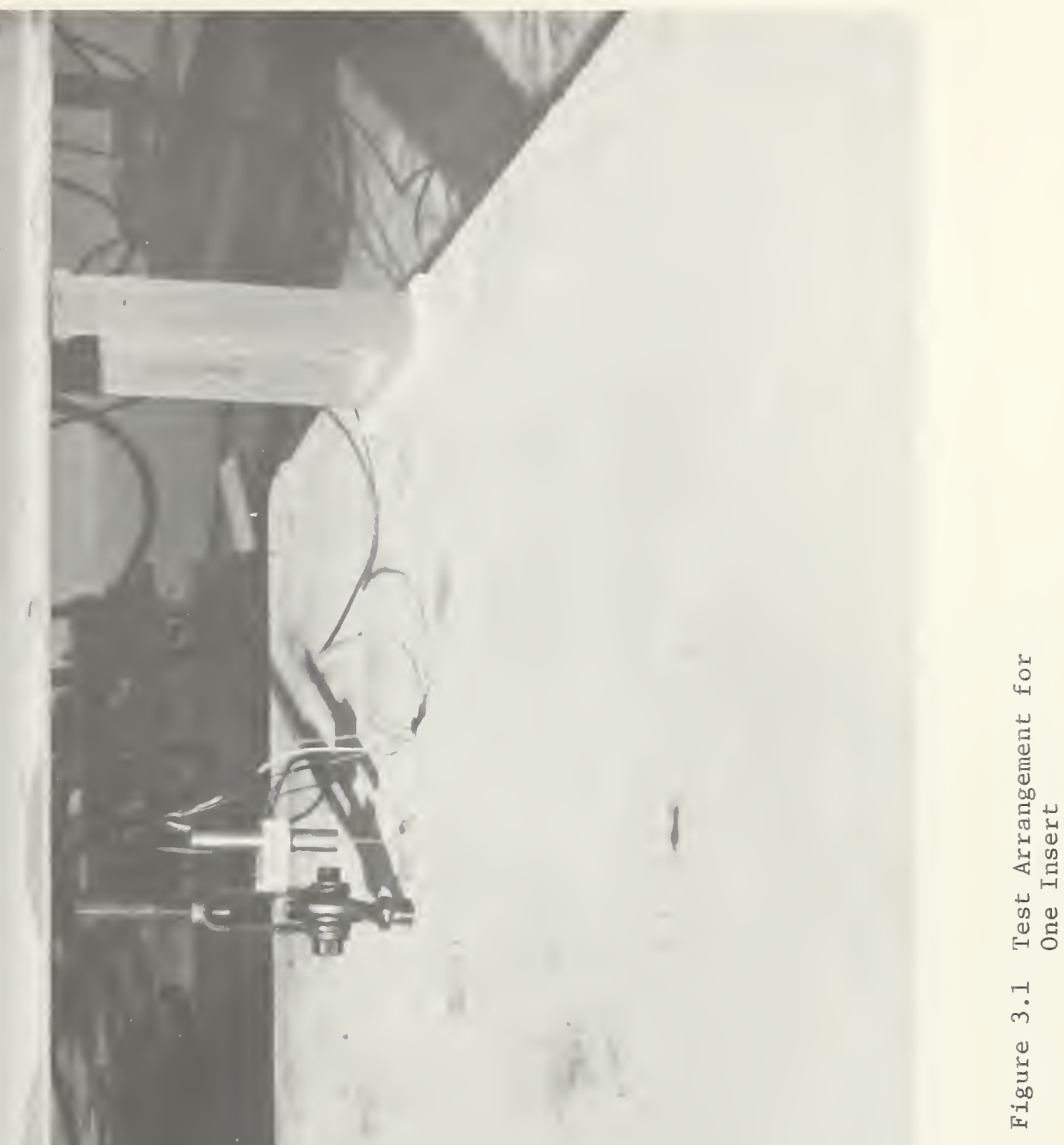




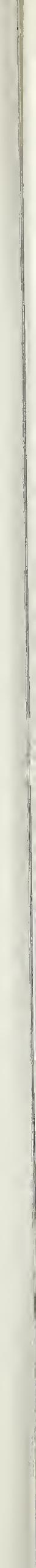




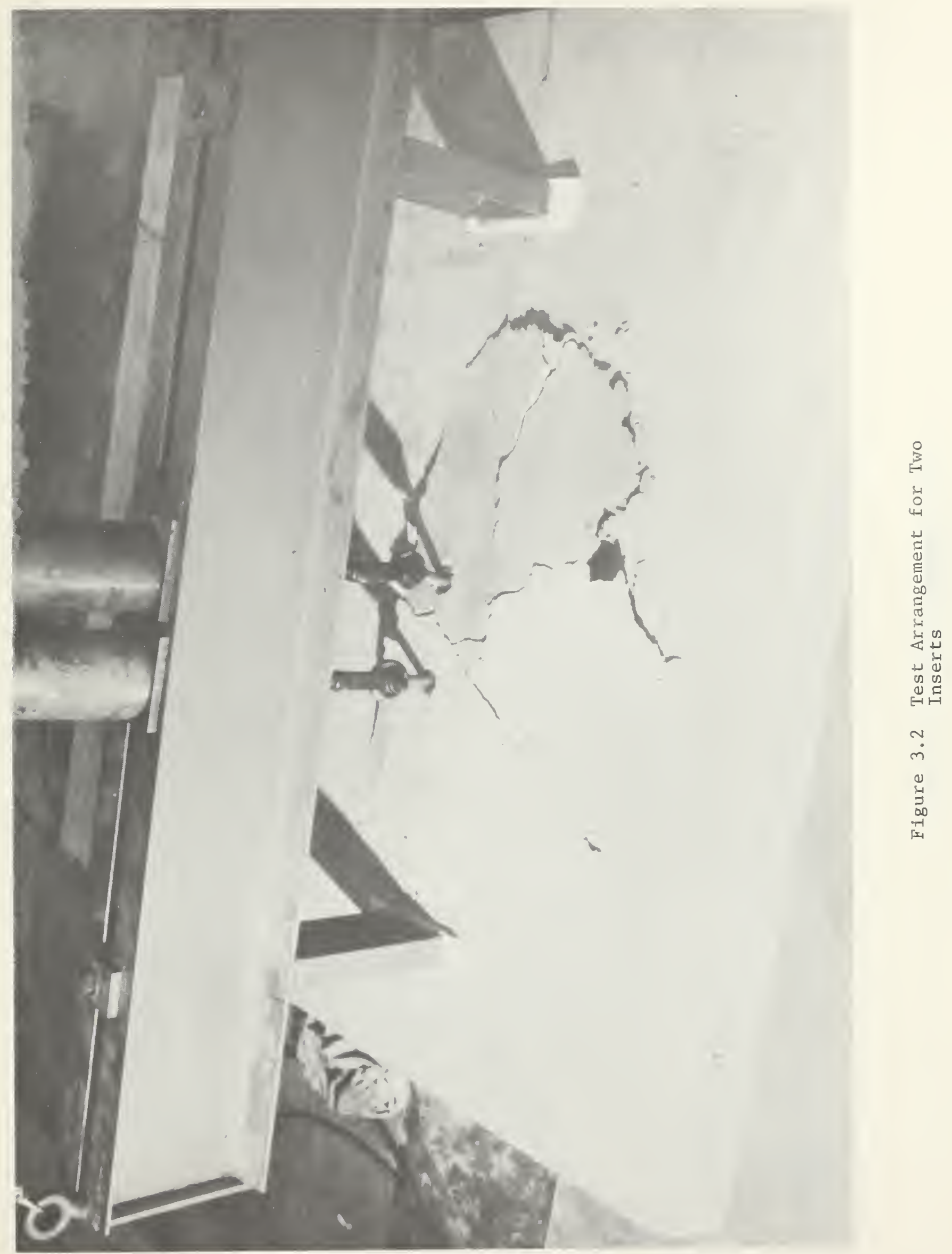





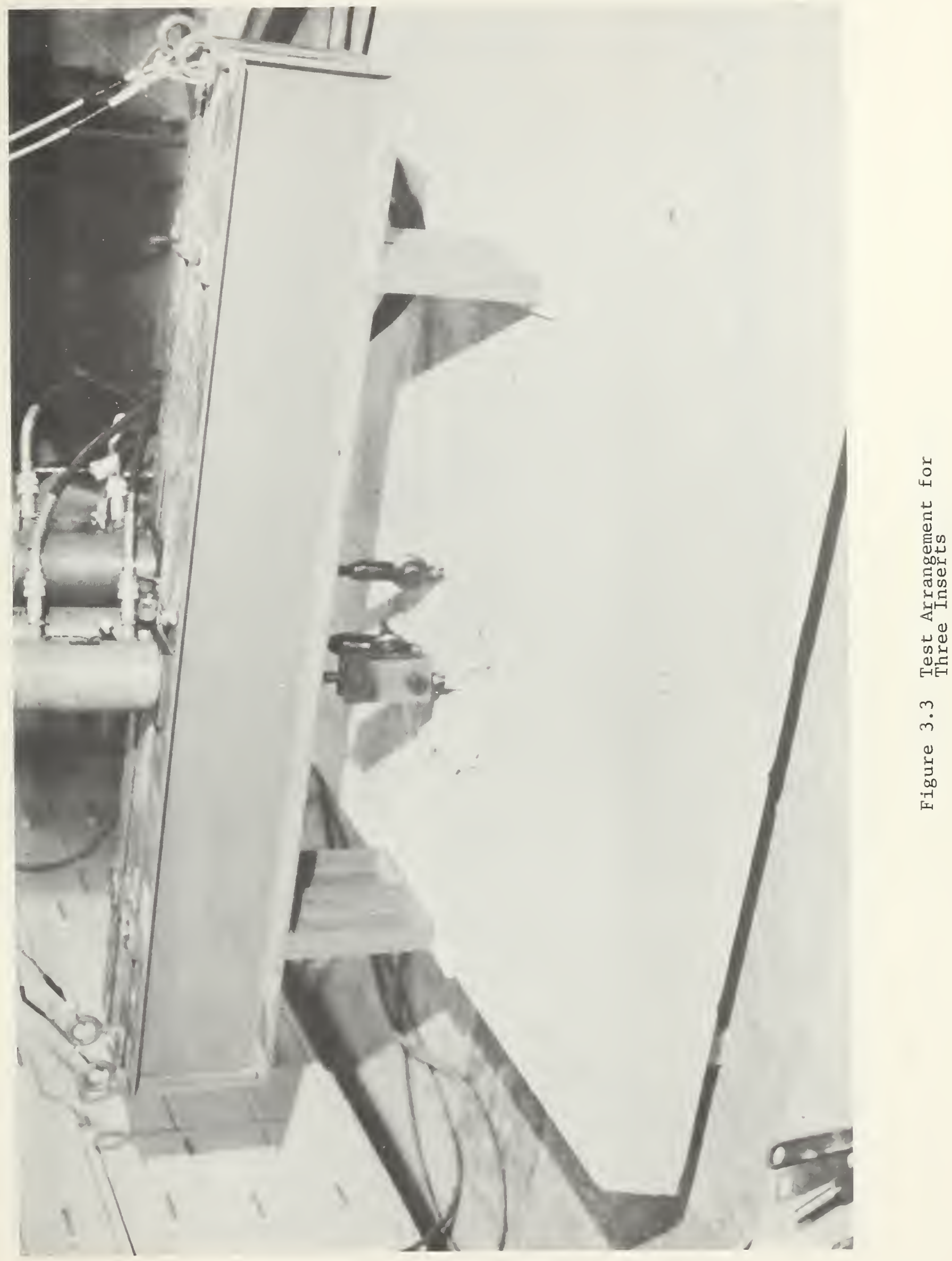





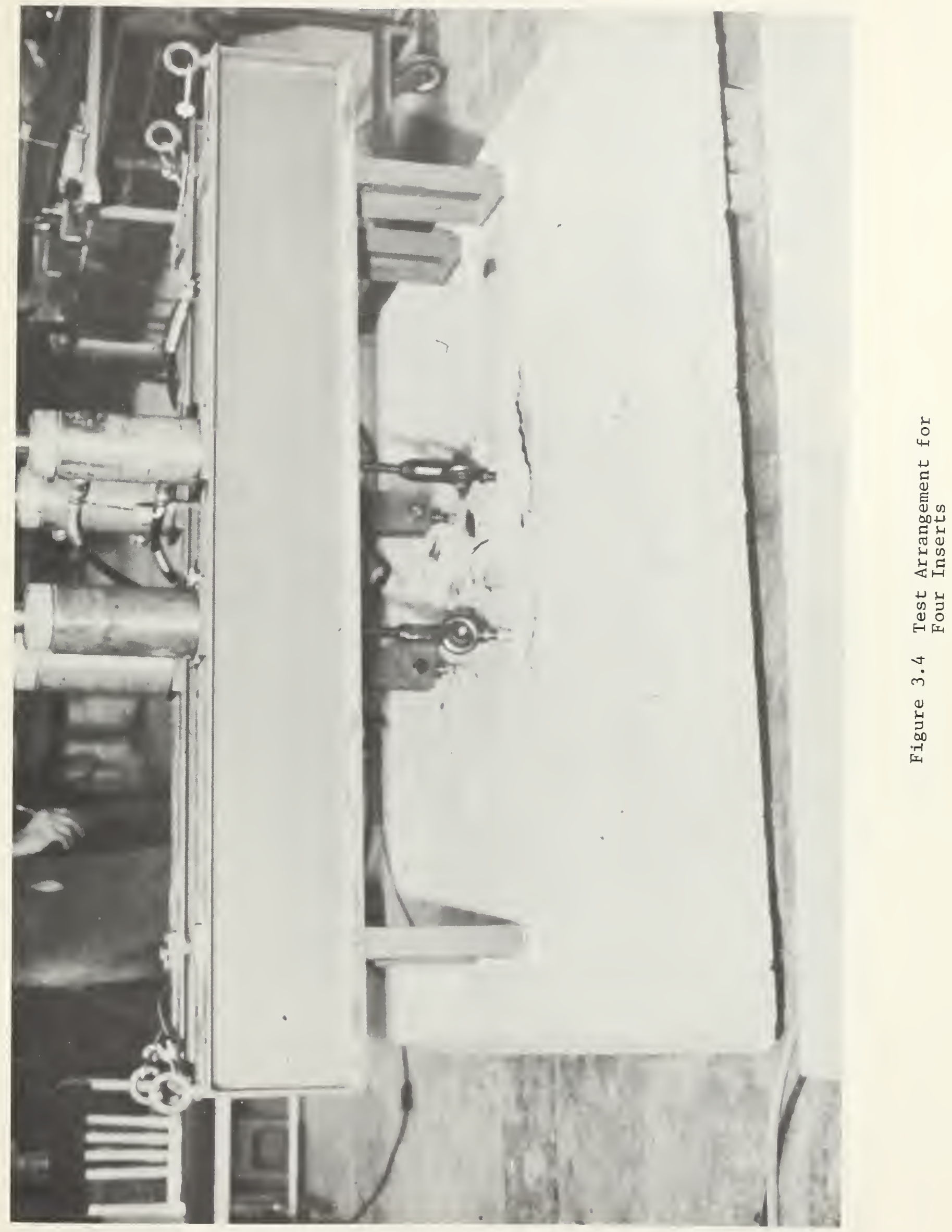





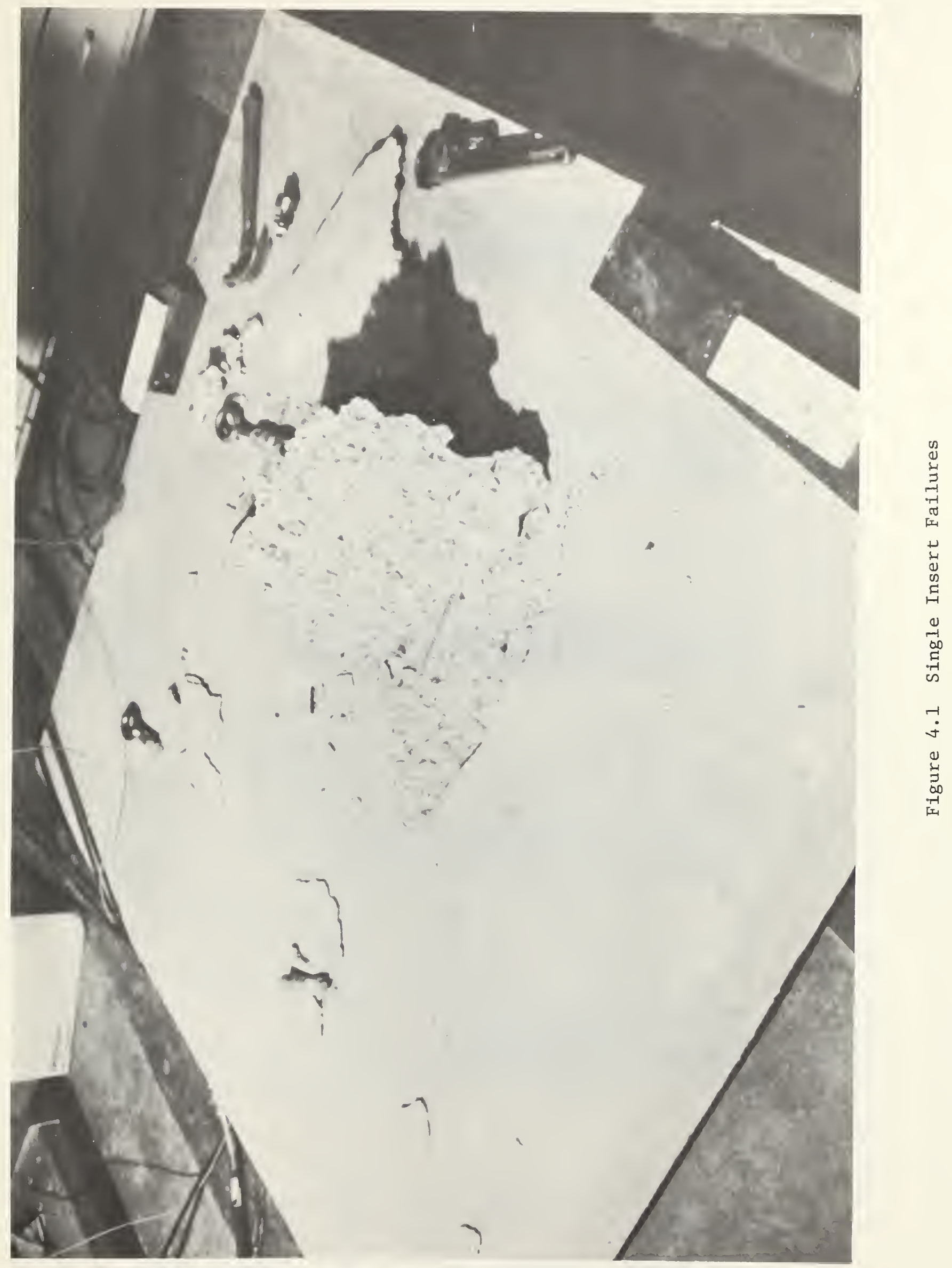





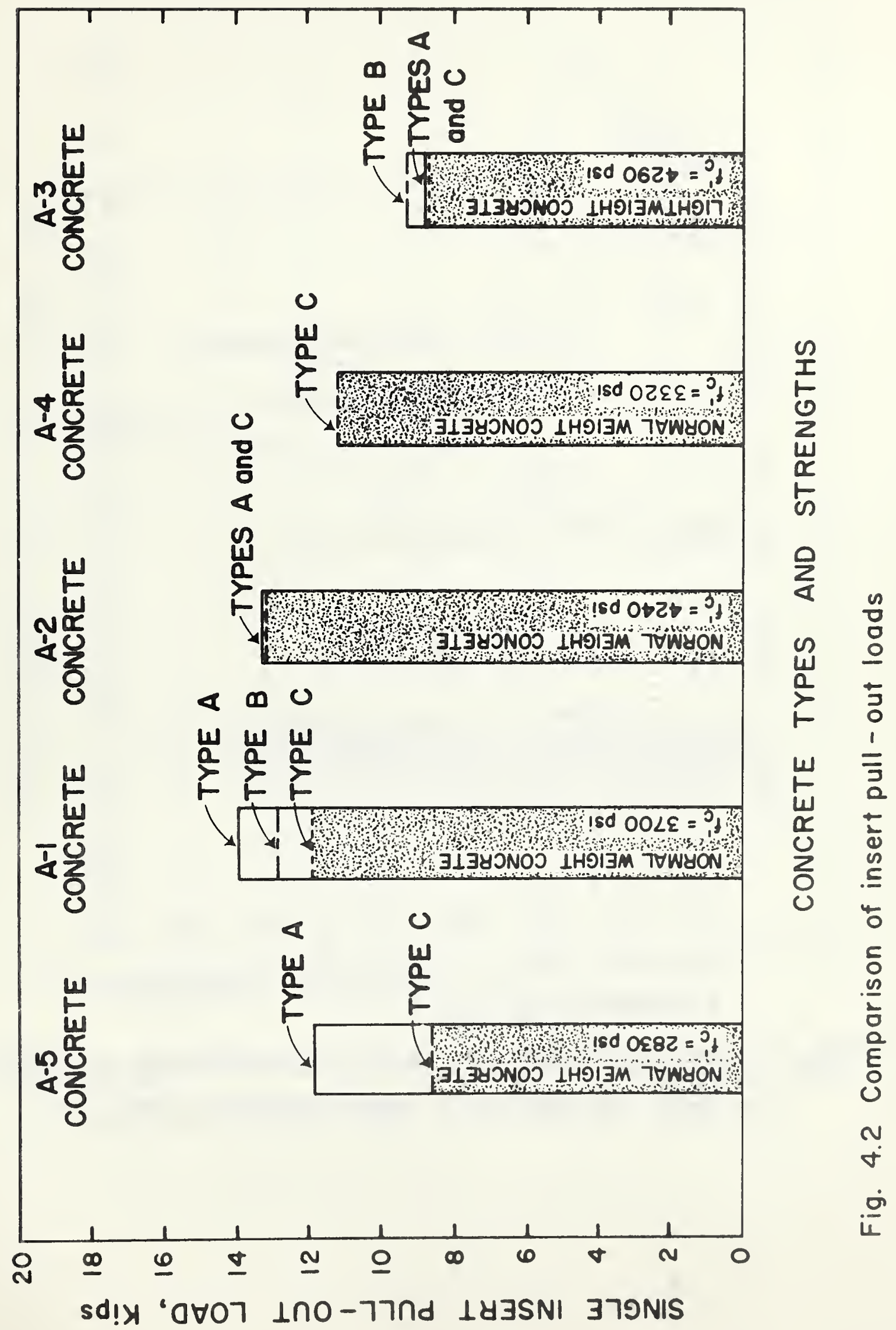




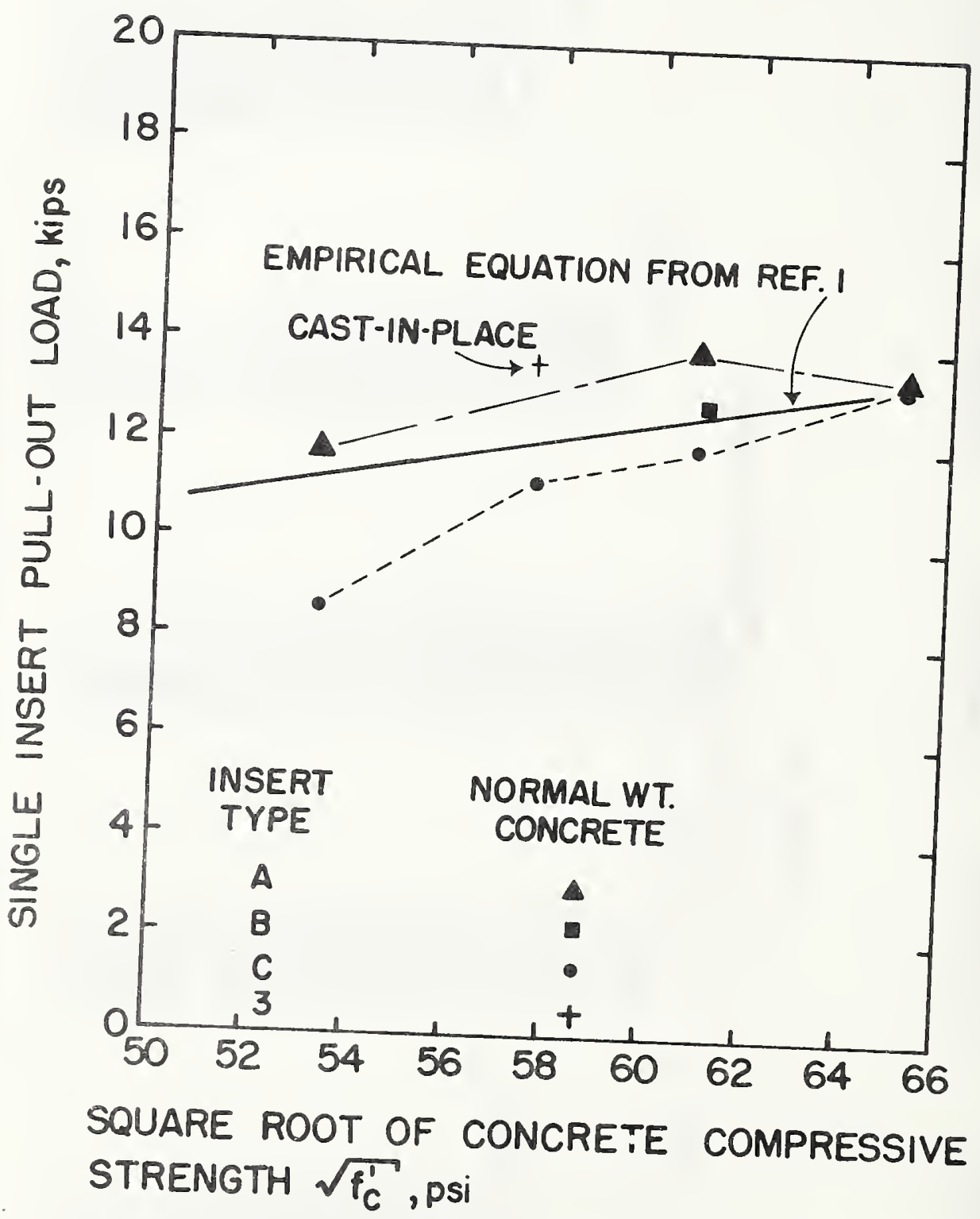

FIGURE 4.3 VARIATION OF PULL-OUT LOAD WITH THE SQUARE ROOT OF CONCRETE COMPRESSIVE STRENGTH 


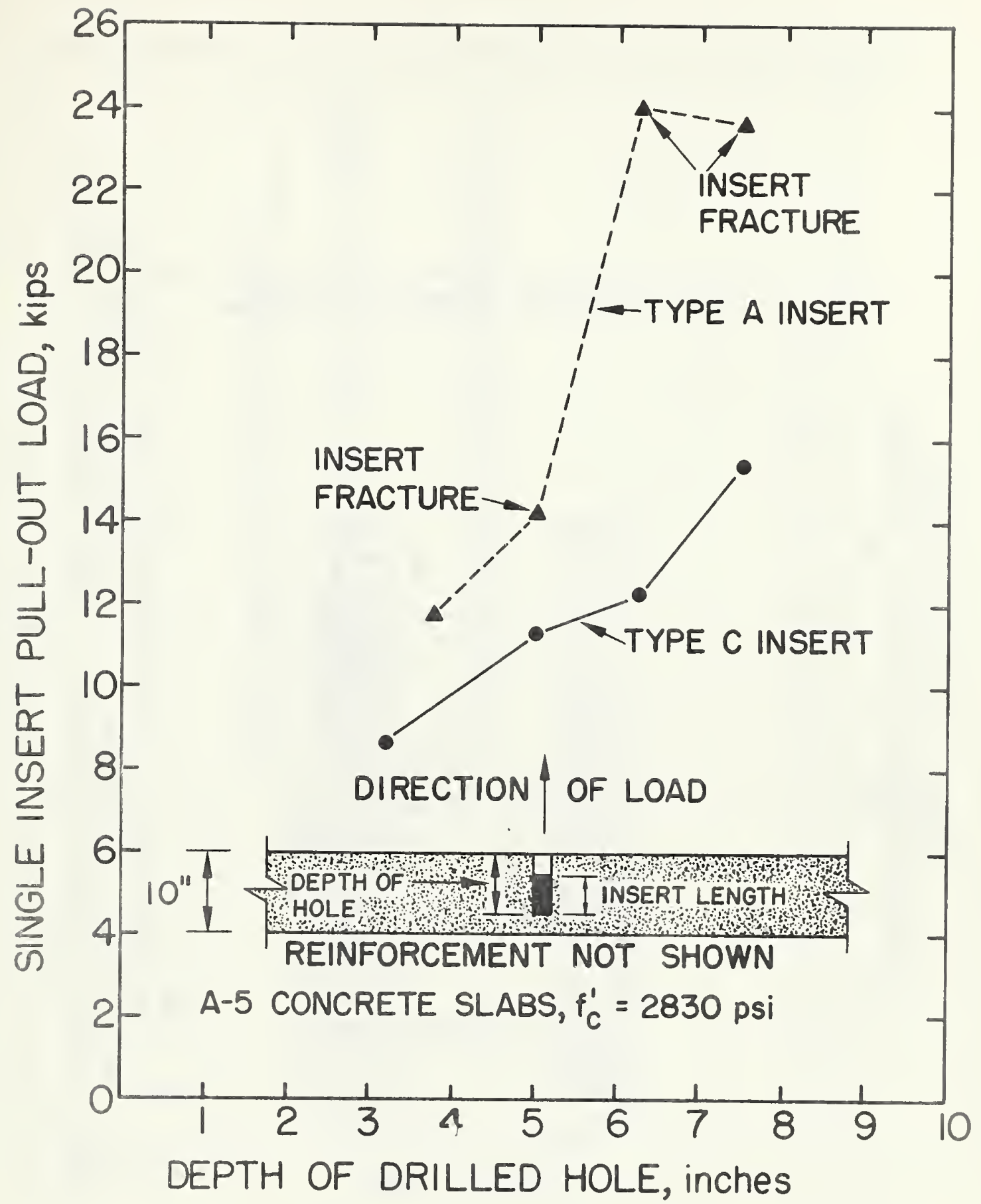

FIGURE 4.4 EFFECT OF DEPTH OF DRILLED HOLE ON PULL-OUT LOAD OF SINGLE INSERTS 


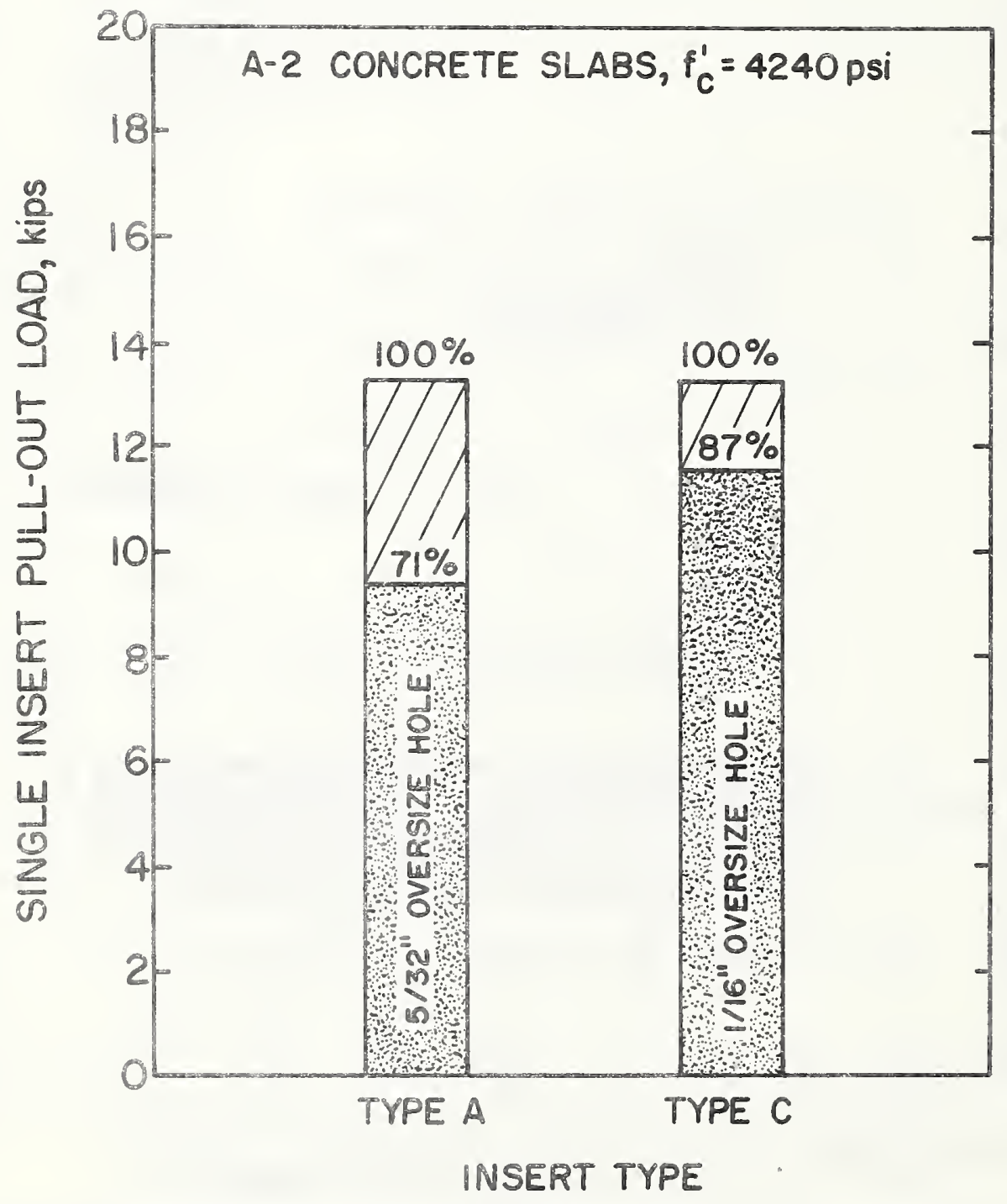

FIGURE 4.5 EFFECT OF OVERSIZE HOLE ON PULL-OUT LOAD OF SINGLE INSERTS 


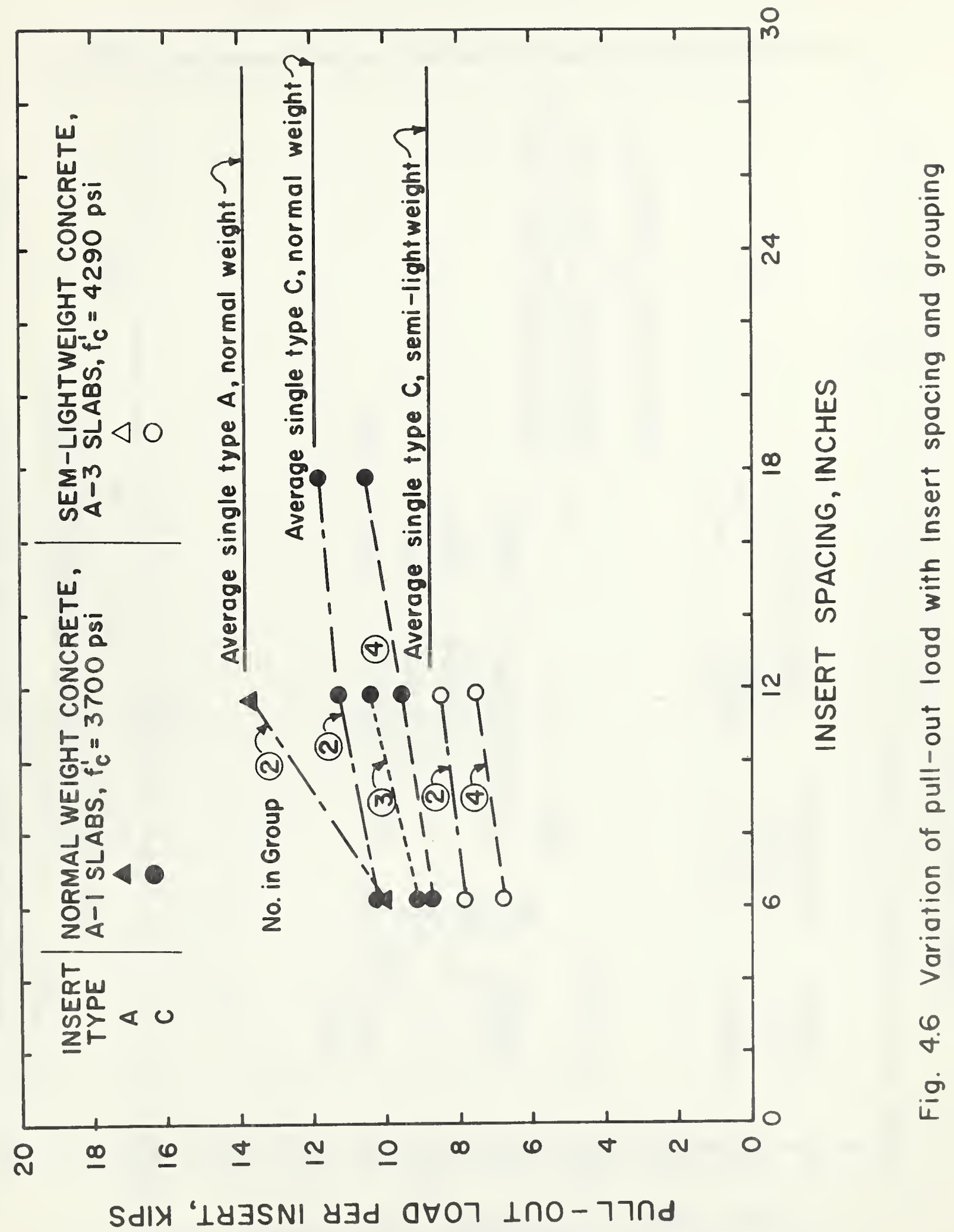




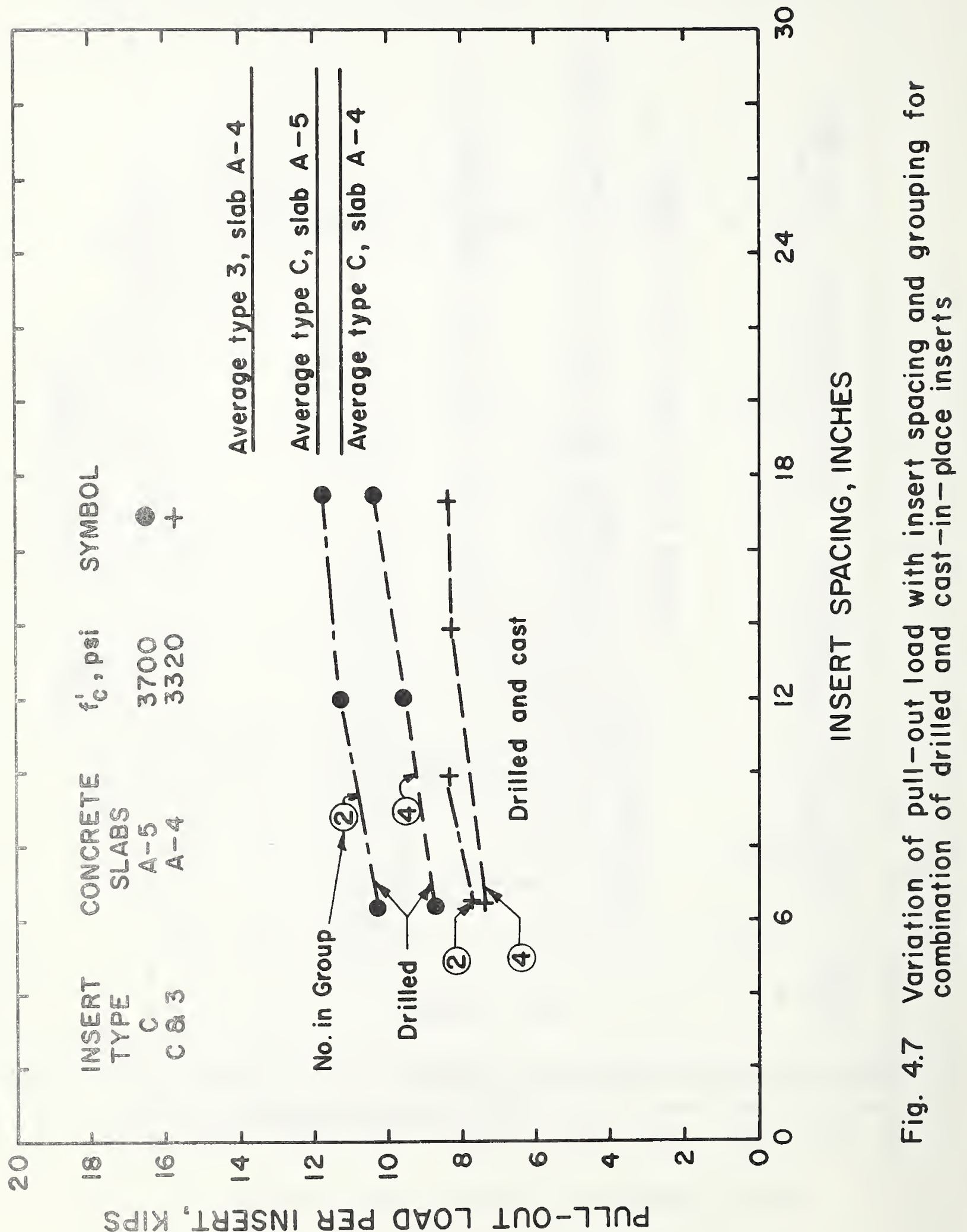




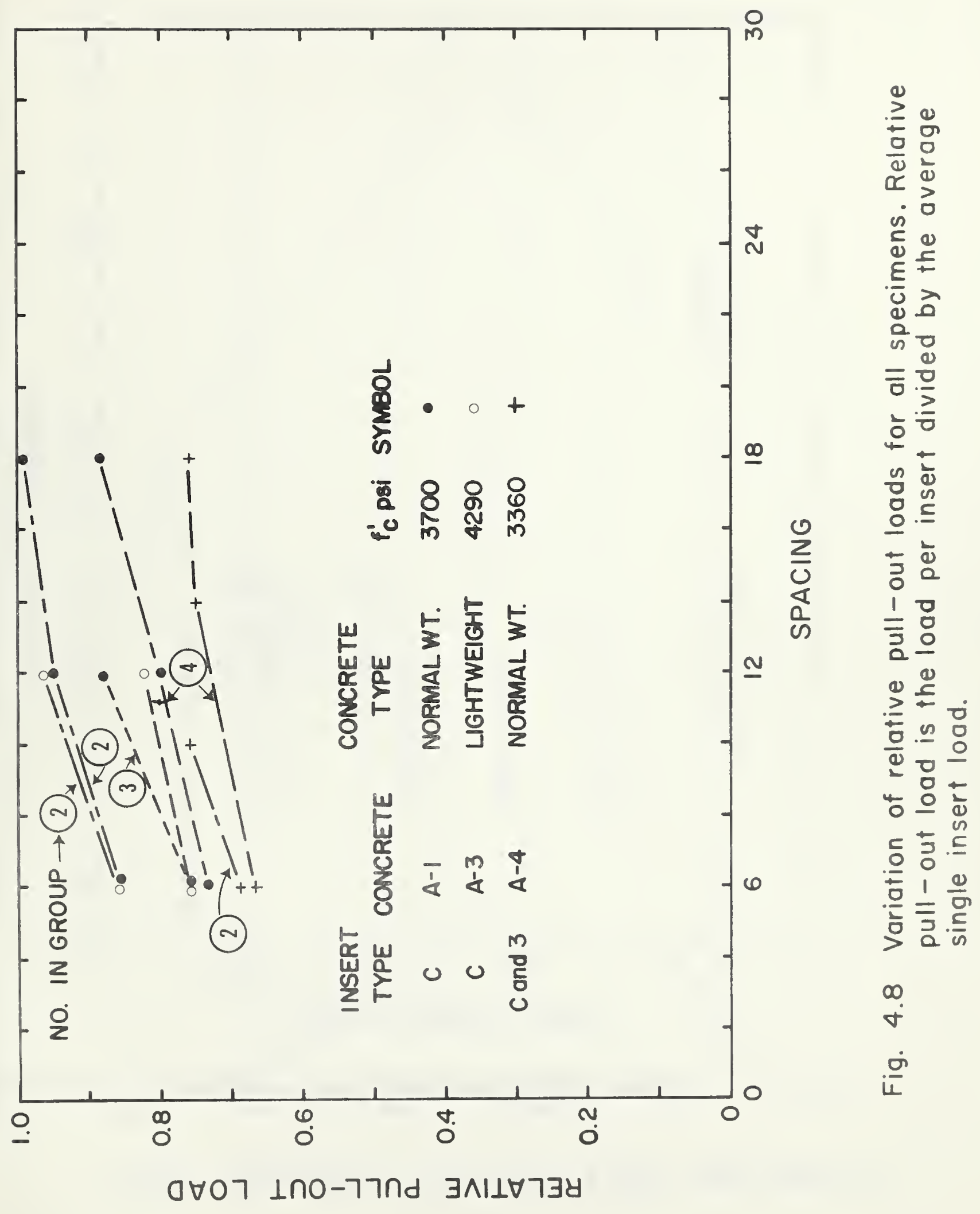




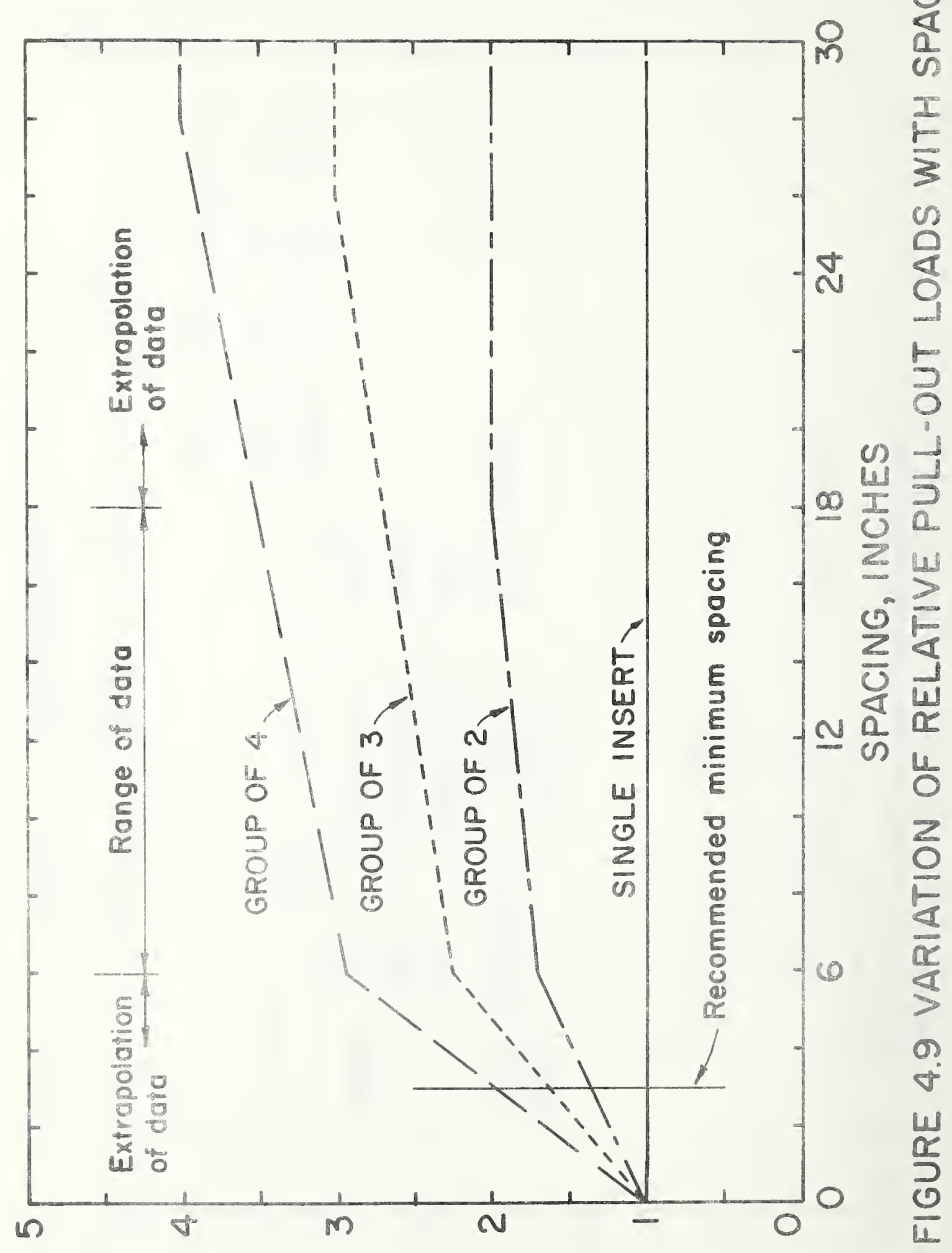

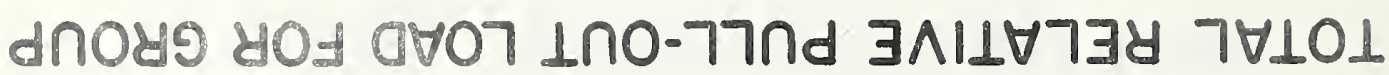




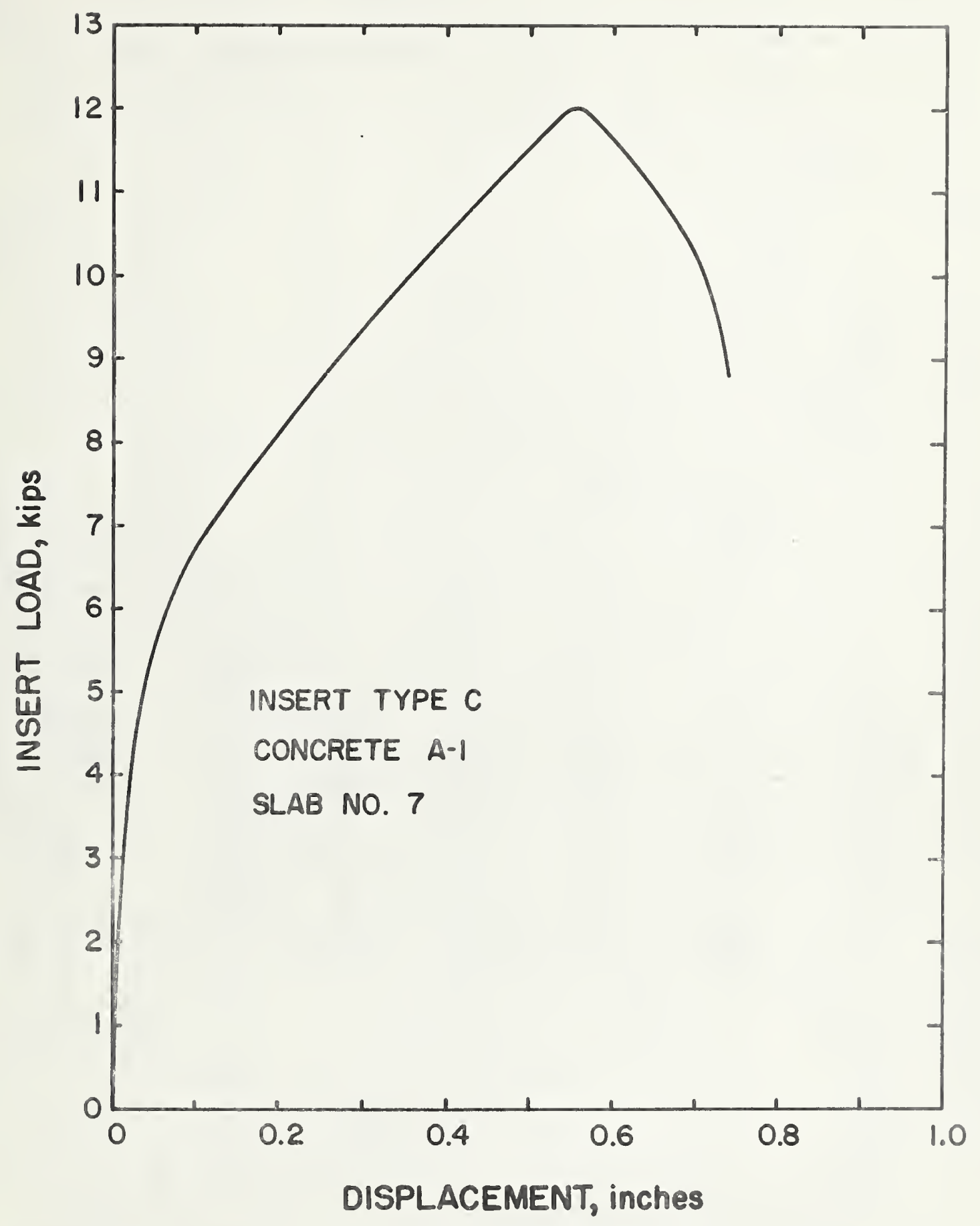

FIGURE 4.10 TYPICAL LOAD-DISPLACEMENT DATA 


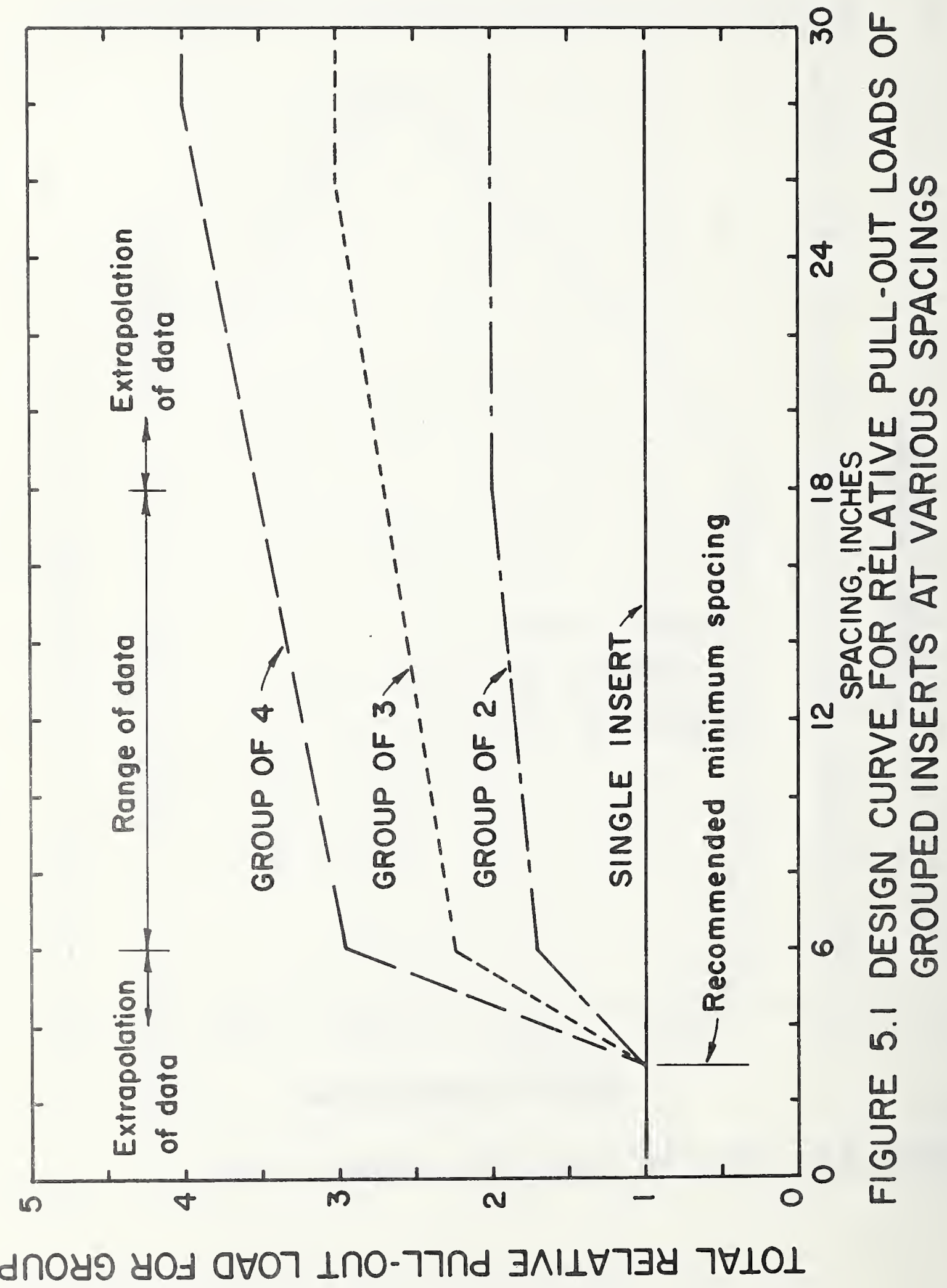


